\title{
Gender Differentiation and Early Labour Market Integration across Europe
}

Emer Smyth 
Emer Smyth

Gender Differentiation and Early Labour Market Integration across Europe 


\section{Smyth, Emer:}

Gender Differentiation and Early Labour Market Integration across Europe / Emer

Smyth -

Mannheim : 2002

(Arbeitspapiere - Mannheimer Zentrum für Europäische Sozialforschung ; 46)

ISSN 1437-8574

Not available in book shops.

Token fee: $€ 2,60$

Purchase: Mannheimer Zentrum für Europäische Sozialforschung (MZES), D - 68131 Mannheim

WWW: http://www.mzes.uni-mannheim.de

\section{Editorial Note:}

Dr Emer Smyth is a Senior Research Officer with the Economic and Social Research Institute, Dublin. Her research interests centre on school to work transitions, gender and the labour market, and school organisation and process. The current paper draws on her involvement in the project 'Evaluation and Analyses of the LFS 2000 Ad-hoc-module on Transitions from School to Work'.

\section{Acknowledgements}

The data used in this paper have been kindly provided by Eurostat. The paper has benefited from discussion with David Raffe, Irena Kogan, Cristina lannelli, Frank Kalter and Maarten Wolbers. I am particularly grateful to Markus Gangl and Walter Müller for their comments on an earlier draft of the paper. 


\section{$\underline{\text { Abstract }}$}

This paper examines gender differentiation in early labour market outcomes across European countries. In spite of the fact that the educational attainment of women has now surpassed that of men in many countries, differences persist in the type of educational courses taken by young women and men. Countries differ in the extent of educational segregation by gender but certain regularities are evident, with health/welfare, education and arts courses dominated by women and engineering courses dominated by men. Countries with higher levels of educational segregation by gender are found to have higher levels of occupational segregation by gender. However, marked gender differences are still apparent between women and men who have received the same kind of education, regardless of the country considered. 


\section{Contents}

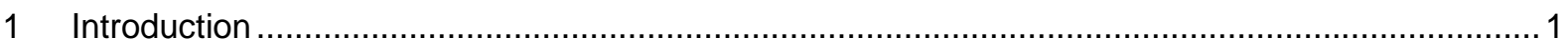

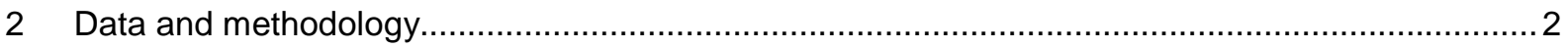

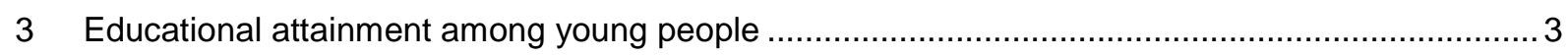

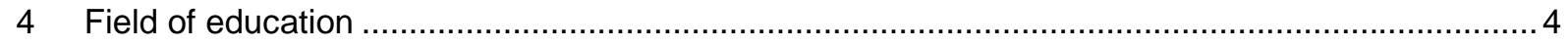

5 Gender differences in labour market integration .............................................................

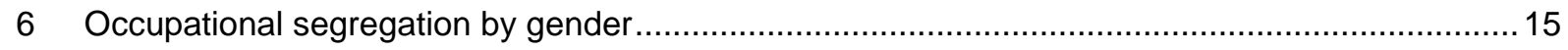

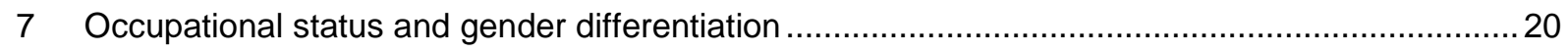

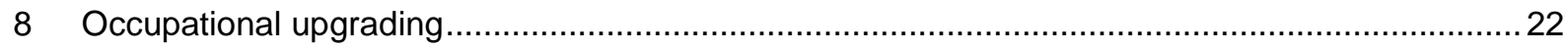

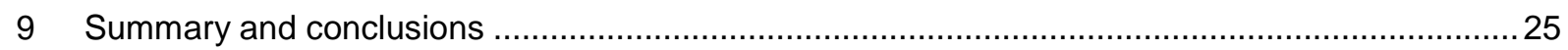

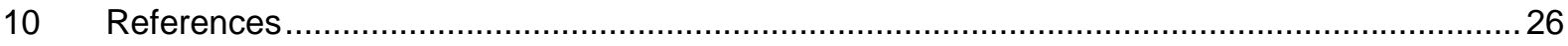

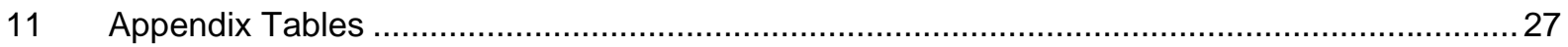




\section{Introduction}

This paper uses data from the Eurostat ad hoc module on school to work transitions to examine gender differentiation in educational outcomes and labour market entry patterns across Europe. It examines the extent to which the nature of gender differentiation may be constructed within different social, economic and cultural contexts (see, for example, Connell, 1987; Rubery and Fagan, 1995). The main research questions addressed are as follows:

1. How do European countries differ in the level and nature of education achieved by young people?

2. Is the nature of gender differentiation in early labour market integration similar across European countries?

3. To what extent is gender differentiation in early labour market integration due to differences in the level and type of education obtained by young women and men?

4. To what extent does gender segregation in the type of education translate into gender segregation in occupational outcomes?

Three sets of hypotheses are tested:

1. The type of differentiation evident within the education/training system will influence the nature of gender differences in educational outcomes. More specifically, in systems with a high level of track differentiation, clear gender differences are likely to be apparent in the type of education received by women and men.

2. The type of differentiation evident within the education/training system will influence the nature of gender differences in transition outcomes. More specifically:

- Occupational segregation by gender will be more evident in track-differentiated systems if strong gender differences are apparent in the field of education followed.

- In track-differentiated systems, gender segregation in labour market outcomes will tend to be mediated by the type of course taken. Thus, young women will enter female-typed occupations or industries because they have taken part in courses oriented towards such outcomes.

- In contrast, in more general systems, gender differences will arise in the interaction between occupational choice and employer preference on entry to the labour market. Thus, direct gender effects on occupational allocation should be stronger in general than in track-differentiated systems.

3. Different dimensions of gender differentiation are not necessarily interrelated. For example, gender segregation may act as a protection against unemployment for female 
labour market entrants in a context where unemployment rates are lower in 'female' occupations. Conversely, young women entrants may be excluded from the labour market if the occupational structure is highly segregated and 'female' jobs are already overcrowded.

The following section describes the data and measures used in the remainder of the paper.

\section{Data and methodology}

The paper draws on data from the Eurostat ad hoc module on school to work transitions which was included in the Labour Force Survey in the second quarter of 2000. For reasons of comparability, data on Ireland, Latvia, Lithuania and Luxembourg are not presented in this paper (see lannelli, 2001). An innovative feature of the ad hoc module on transitions was the collection of information on the field of education studied by young people before leaving education. However, some problems relating to comparability arose in the implementation of the module (see lannelli, 2001). In Denmark, Italy, Portugal and the United Kingdom the information on field of education related to the highest level of education completed rather than the level when leaving education for the first time. For this reason, most analyses in the paper exclude these countries.

The paper focuses on a number of different dimensions of early labour market experiences among young women and men. Firstly, the proportion of young people who have obtained a first significant job by the time of the interview is taken as an indicator of successful labour market integration. 'First significant job' refers to a job that has lasted at least six months and is more than twenty hours a week. For the purposes of the paper, young people who described themselves as not having had a first significant job but had been in employment for six months or more are reclassified as having had a first significant job. Analyses of labour market integration are supplemented with analyses of labour force participation and current unemployment. Secondly, measures of educational and occupational segregation are derived using an index of dissimilarly in order to compare the levels of segregation across countries. Thirdly, the paper focuses on the extent to which young women and men enter predominantly male, mixed or predominantly female occupations. Fourthly, occupational status is measured using the International Socio-economic Index (ISEI) scale (see Ganzeboom and Treiman, 1996). Finally, occupational upgrading is based on the extent to which young people have increased their occupational status between their first significant job and their current job.

Analyses of labour market integration, labour force participation, unemployment and occupational upgrading use a series of logistic regression models. Analysis of gender-typing of occupation uses a multinomial logistic regression model. Analysis of occupational status uses linear regression modelling techniques. In all of the models, the focus is not on country 
differences per se but rather on the relative size of gender differences across the different European countries analysed. For the most part, Spain is used as the base category in the analyses due to the data quality and relative lack of missing information.

The paper opens by discussing differences across European countries in the level and type of education obtained by young women and men.

\section{Educational attainment among young people}

\section{Figure 1 Female representation by level of education}

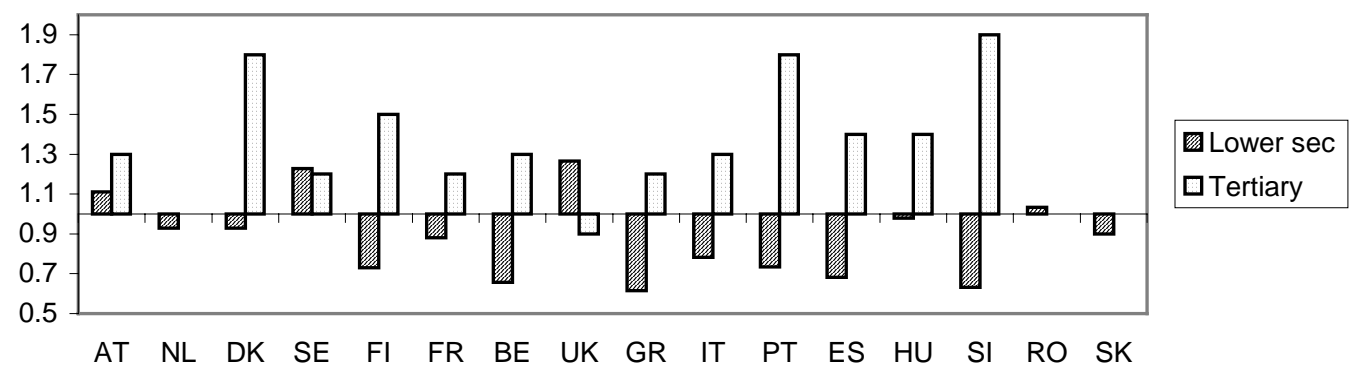

Recent decades have been characterised by considerable educational expansion across Europe, particularly among young women. In some European countries, female educational attainment (in terms of educational level) has now surpassed that of men (Müller and Wolbers, 1999). Figure 1 indicates female representation by lower secondary and tertiary levels in the countries concerned. This is derived from the ratio between the proportion of females at a particular educational level and the proportion of males at that level. A ratio greater than one indicates the over-representation of women in a particular educational category while a ratio below one indicates under-representation.

Three groups of countries emerge from the data. In the first group, female leavers are relatively advantaged in terms of their educational attainment; that is, they are significantly underrepresented among lower secondary leavers and over-represented among tertiary leavers. Countries in this group include Belgium, Spain, Finland, Greece, Italy and Portugal. In the second group, a higher proportion of females than males leave at the tertiary level but there is no significant difference in their distribution between the lower and upper secondary levels. This group includes Denmark, France, Hungary, and Slovenia. Only in the United Kingdom are young women found to be under-represented among tertiary leavers. In the remaining countries (Austria, the Netherlands, Romania, Slovakia and Sweden), no significant gender differences are found in the educational attainment levels of system leavers. 


\section{Field of education}

In all of the countries considered, significant gender differences were evident in the field of education studied at both upper secondary and tertiary levels. ${ }^{1}$ The extent of gender differentiation in type of education can be analysed using an index of dissimilarity measure which indicates the proportion of males (or females) who would need to 'change' fields in order to achieve an equal distribution across categories by gender. ${ }^{2}$ Indices of dissimilarity tend to be sensitive to the number of categories considered with more aggregated classifications often concealing gender segregation. Indices are also likely to be sensitive to sample size, in particular to the greater clustering in certain categories potentially found using small samples.

Field of education was classified into twenty-five detailed categories which could be aggregated into nine broad categories. Indices of dissimilarity at upper secondary and tertiary levels were calculated for both classifications: firstly, to allow for the existence of gender segregation within broader categories (for example, the physical sciences may differ in their gender profile from the life sciences); secondly, to increase comparability across countries as in Romania and Sweden only the broader classification was employed; and thirdly, to allow for the fact that apparent segregation at the more detailed level may reflect sampling variation (especially where sample sizes are relatively small) rather than gender segregation per se.

The indices of dissimilarity for both the more detailed and broader classifications are presented in Table 1. At upper secondary level, gender segregation was found to be greatest in Austria, France and Hungary, with the lowest levels found in Greece and Romania. In the case of Greece, the low degree of gender segregation reflects the fact that the majority (62\%) of students had taken general courses. In overall terms, gender segregation is somewhat lower in countries where a greater proportion of young people leave the upper secondary level having taken general courses. A correlation of $r=-0.74$ is found between the proportion of young people in general tracks at upper secondary level and the degree of gender segregation found at this level. At tertiary level, gender segregation was greatest in Austria, Finland and Hungary, and lowest in the Netherlands and Belgium. In general, segregation was found to be greater using the more detailed classification, indicating that broad categories of educational field may encompass subject areas with very different gender profiles.

${ }^{1}$ Lower secondary education was usually more general in nature so field of education is not considered for those who left from this level.

${ }^{2}$ This is calculated by summing the absolute differences in the proportion of males and females in each educational field and dividing the total by two. 
Fields of education were classified in terms of their 'female-intensity'; the original intention was to divide fields into 'female-intensive' (>60\% female), 'mixed' (40-60\% female) and 'maleintensive' $(<40 \%$ female) subject areas. However, as countries differ in their female representation at the different educational levels, the cut-offs were adjusted accordingly. General courses were assigned to a separate category.

Table 1 Gender segregation by field of education (index of dissimilarity)

\begin{tabular}{lccccc}
\hline Level of education & \multicolumn{3}{c}{ Upper secondary } & \multicolumn{2}{c}{ Tertiary } \\
Field categories & Broad & Detailed & $\begin{array}{c}\text { \% in general } \\
\text { courses }\end{array}$ & Broad & Detailed \\
\hline Austria & 58.9 & 60.2 & 9.4 & 44.5 & 52.2 \\
Netherlands & 38.8 & 42.2 & 20.4 & 26.9 & 32.1 \\
Sweden & 37.8 & n.a. & 13.9 & 41.0 & n.a. \\
Finland & 35.6 & 38.1 & 34.2 & 44.2 & 50.1 \\
France & 57.6 & 59.0 & 2.3 & 33.1 & 34.5 \\
Belgium & 32.4 & 33.0 & 43.5 & 28.4 & 35.7 \\
Greece & 16.7 & 17.4 & 62.9 & 31.4 & 32.6 \\
Spain & 32.1 & 32.9 & 51.5 & 38.2 & 40.3 \\
Hungary & 47.7 & 57.7 & 11.5 & 41.8 & 42.4 \\
Slovenia & 47.1 & 54.2 & 0.4 & 37.3 & 46.0 \\
Romania & 22.7 & n.a. & 14.3 & 38.6 & n.a. \\
Slovakia & 43.3 & 47.2 & 8.2 & 38.9 & 40.5 \\
\hline
\end{tabular}

Tables 2 and 3 present the profiles of subjects at upper secondary and tertiary levels. The more aggregated classification is used due to the small numbers in some of the detailed subject areas. There are certain commonalities across countries in the gender-typing of subject areas. In all countries considered, engineering courses at upper secondary level tend to be male-intensive while health/welfare, arts/humanities, education courses and social science/business courses are female-intensive. ${ }^{3}$ Science and agriculture courses tend to be male or mixed in profile. In the case of agriculture, the profile appears to be somewhat less male-dominated in the Eastern European countries than in the Western European countries. The gender profile of those taking general and services courses varies by country, although the profile is predominantly female in the majority of countries.

${ }^{3}$ In the latter case, the exception is France where education courses are mixed in profile. However, this pattern should be interpreted with caution since fewer than one per cent of the upper secondary leavers in the sample had taken education courses. 


\section{Table 2 Female-intensity of different fields of education at upper secondary level}

\begin{tabular}{|c|c|c|c|c|c|c|c|c|}
\hline & Education & Arts & $\begin{array}{c}\text { Social/ } \\
\text { business }\end{array}$ & Science & Engineering & Agriculture & $\begin{array}{l}\text { Health/ } \\
\text { welfare }\end{array}$ & Services \\
\hline Austria & $F$ & $F$ & $\mathrm{~F}$ & $\mathrm{M}$ & $\mathrm{M}$ & $\mathrm{N}$ & $\mathrm{F}$ & $\mathrm{F}$ \\
\hline Netherlands & . & . & $\mathrm{F}$ & . & $\mathrm{M}$ & (M) & $\mathrm{F}$ & $F$ \\
\hline Sweden & $\mathrm{F}$ & $\mathrm{F}$ & $\mathrm{F}$ & $\mathrm{M}$ & $\mathrm{M}$ & $\mathrm{N}$ & $\mathrm{F}$ & $\mathrm{F}$ \\
\hline Finland & . & $\mathrm{F}$ & $F$ & . & $\mathrm{M}$ & $\mathrm{F}$ & $\mathrm{F}$ & $F$ \\
\hline France & $\mathrm{N}$ & $\mathrm{F}$ & $F$ & $\mathrm{~N}$ & $M$ & $M$ & $\mathrm{~F}$ & $F$ \\
\hline Belgium & $\mathrm{F}$ & $\mathrm{F}$ & $\mathrm{F}$ & $\mathrm{M}$ & $\mathrm{M}$ & $\mathrm{M}$ & $\mathrm{F}$ & $\mathrm{F}$ \\
\hline Greece & $\mathrm{F}$ & $\mathrm{F}$ & $\mathrm{F}$ & $\mathrm{N}$ & $\mathrm{M}$ & . & $\mathrm{F}$ & $\mathrm{N}$ \\
\hline Spain & $(F)$ & $\mathrm{F}$ & $\mathrm{F}$ & $\mathrm{M}$ & $\mathrm{M}$ & $\mathrm{M}$ & $\mathrm{F}$ & $\mathrm{F}$ \\
\hline Hungary & $\mathrm{F}$ & $(F)$ & $\mathrm{F}$ & $\mathrm{M}$ & $\mathrm{M}$ & $\mathrm{N}$ & $\mathrm{F}$ & $\mathrm{F}$ \\
\hline Slovenia & $(F)$ & $(F)$ & $\mathrm{F}$ & $(F)$ & $\mathrm{M}$ & $\mathrm{N}$ & $\mathrm{F}$ & $\mathrm{N}$ \\
\hline Romania & $\mathrm{F}$ & $\mathrm{F}$ & $\mathrm{F}$ & $\mathrm{F}$ & $\mathrm{N}$ & $\mathrm{N}$ & $\mathrm{F}$ & $\mathrm{N}$ \\
\hline Slovakia & $\mathrm{F}$ & $\mathrm{F}$ & $\mathrm{F}$ & $\mathrm{N}$ & $\mathrm{M}$ & $\mathrm{N}$ & $\mathrm{F}$ & $\mathrm{F}$ \\
\hline
\end{tabular}

Table 3 Female-intensity of different fields of education at tertiary education level

\begin{tabular}{|c|c|c|c|c|c|c|c|c|}
\hline & Education & Arts & $\begin{array}{c}\text { Social/ } \\
\text { business }\end{array}$ & Science & Engineering & Agriculture & $\begin{array}{l}\text { Health/ } \\
\text { welfare }\end{array}$ & Services \\
\hline Austria & $\mathrm{F}$ & $\mathrm{F}$ & $\mathrm{N}$ & $M$ & $M$ & $M$ & $\mathrm{~F}$ & $M$ \\
\hline Netherlands & $\mathrm{N}$ & $(\mathrm{F})$ & $\mathrm{N}$ & $(\mathrm{M})$ & $\mathrm{M}$ & . & $\mathrm{F}$ & . \\
\hline Sweden & $\mathrm{F}$ & $\mathrm{F}$ & $\mathrm{N}$ & $\mathrm{M}$ & $M$ & . & $\mathrm{F}$ & . \\
\hline Finland & $\mathrm{F}$ & $\mathrm{F}$ & $\mathrm{N}$ & $\mathrm{N}$ & $\mathrm{M}$ & $(\mathrm{N})$ & $\mathrm{F}$ & $\mathrm{N}$ \\
\hline France & $\mathrm{F}$ & $\mathrm{F}$ & $\mathrm{N}$ & $M$ & $\mathrm{M}$ & $M$ & $\mathrm{~F}$ & $\mathrm{~N}$ \\
\hline Belgium & $F$ & $\mathrm{~N}$ & $\mathrm{~N}$ & $\mathrm{M}$ & $\mathrm{M}$ & $\mathrm{N}$ & $\mathrm{F}$ & $\mathrm{N}$ \\
\hline Greece & $\mathrm{F}$ & $\mathrm{F}$ & $\mathrm{N}$ & $M$ & $\mathrm{M}$ & $\mathrm{M}$ & $\mathrm{N}$ & $\mathrm{M}$ \\
\hline Spain & $\mathrm{F}$ & $\mathrm{N}$ & $\mathrm{F}$ & $\mathrm{N}$ & $M$ & $\mathrm{M}$ & $\mathrm{F}$ & $\mathrm{F}$ \\
\hline Hungary & $\mathrm{F}$ & $\mathrm{F}$ & $\mathrm{N}$ & $\mathrm{M}$ & $\mathrm{M}$ & $\mathrm{M}$ & $\mathrm{N}$ & $\mathrm{M}$ \\
\hline Slovenia & $(F)$ & $(F)$ & $\mathrm{F}$ & $\mathrm{N}$ & $\mathrm{M}$ & $(\mathrm{N})$ & $(\mathrm{N})$ & (M) \\
\hline Romania & $\mathrm{F}$ & $\mathrm{F}$ & $\mathrm{F}$ & $\mathrm{F}$ & $M$ & $\mathrm{M}$ & $\mathrm{F}$ & $\mathrm{M}$ \\
\hline Slovakia & $\mathrm{F}$ & $\mathrm{F}$ & $\mathrm{F}$ & $\mathrm{F}$ & $M$ & $M$ & $\mathrm{~N}$ & $M$ \\
\hline
\end{tabular}

M: $>60 \%$ male, $\mathrm{F}:>60 \%$ female, $\mathrm{N}: 40-60 \%$ female 
At tertiary level, health/welfare, arts/humanities and education remain female-intensive while engineering courses remain male-intensive. Social/business courses become more mixed in profile than at upper secondary level while service courses become somewhat more divergent in their gender profile than at upper secondary level.

Therefore, in spite of differences across countries in the type of education taken by leavers, there are certain commonalities in the gender-typing of certain subject areas. In other cases, however, the gender-typing of educational fields is societally specific.

\section{Gender differences in labour market integration}

Figure 2 shows the proportion of young people who had achieved a first significant job by the time of the interview. It should be noted that a few of the countries (Finland, the Netherlands and Sweden) differ from the others in taking a time-span of five years since leaving education for the first time, a pattern which will have implications for the degree of labour market integration observed. Compared with other countries, those in Romania (male and female) are less likely to have obtained a significant job within ten years of leaving education. In Austria, Belgium, Spain, France, Greece and Hungary, young women are significantly less likely to have entered stable employment than young men. However, as the nature of gender differences varies across the countries examined, it is difficult to disentangle the effects of gender from those of educational level and type.

Figure 2 Proportion who have obtained a first significant job

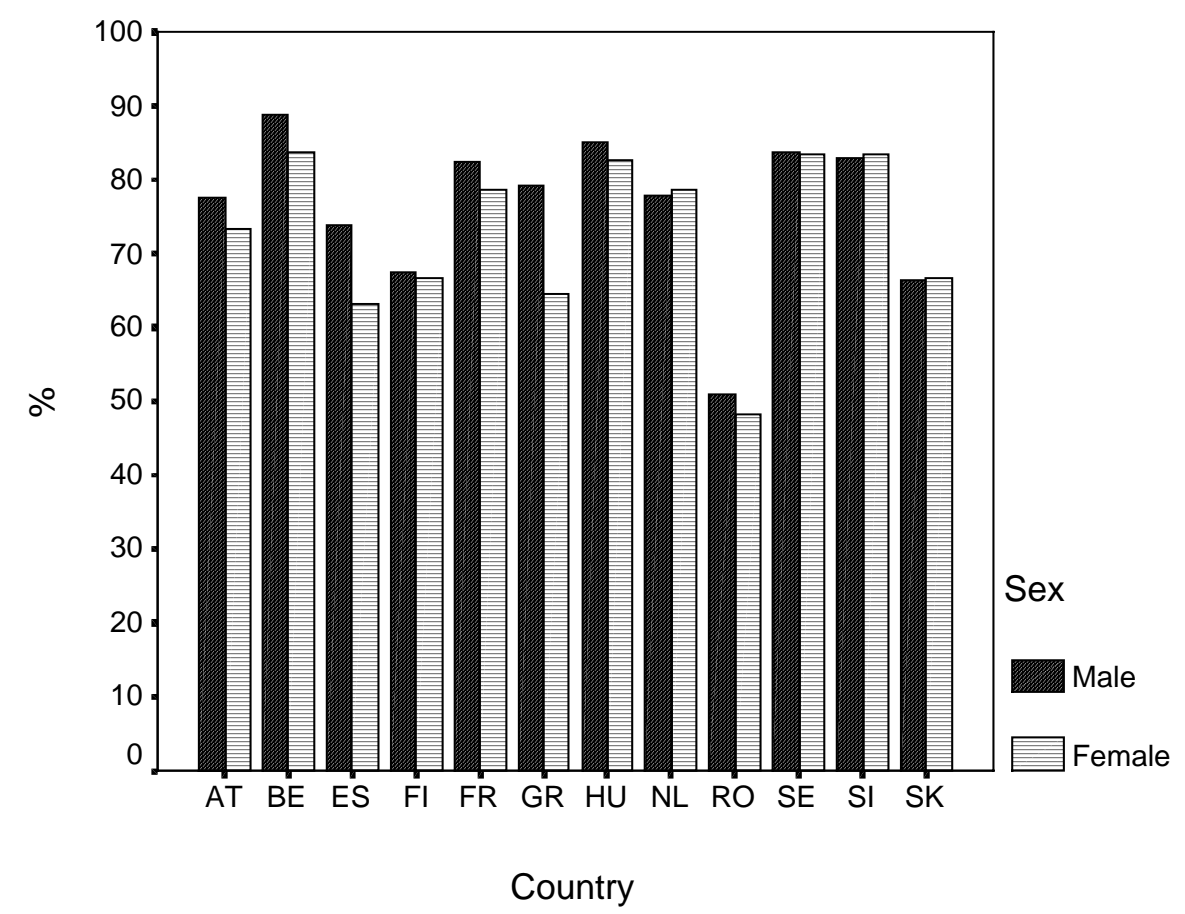


Table 4 Logistic regression model of obtaining a first significant job
(1)
(2)
(3)
(4)
(5)
(6)

\begin{tabular}{|c|c|c|c|c|c|c|}
\hline Intercept & 0.057 & $0.140^{* \star *}$ & $-0.176^{\star \star *}$ & -0.046 & -0.123 & $-0.206^{* * *}$ \\
\hline $\begin{array}{l}\text { Female } \\
\text { (Base: male) }\end{array}$ & $-0.439^{* * *}$ & $-0.718^{* * *}$ & $-0.736^{* *}$ & $-0.715^{\star \star \star}$ & $-0.598^{\star * *}$ & $-0.476^{\star * *}$ \\
\hline $\begin{array}{l}\text { Time since leaving } \\
\text { education (months) } \\
\text { Educational level: }\end{array}$ & $0.017^{\star * *}$ & $0.019^{\star \star \star}$ & $0.020^{* * *}$ & $0.020^{* * *}$ & $0.020^{\star * *}$ & $0.020^{* * *}$ \\
\hline Lower secondary & & $-0.988^{\star \star *}$ & $-0.651^{* * *}$ & $-0.626^{\star * *}$ & $-0.486^{\star * *}$ & $-0.538^{* * *}$ \\
\hline $\begin{array}{l}\text { Tertiary } \\
\text { (Base: Upper secondary) } \\
\text { GenderEducational } \\
\text { level: }\end{array}$ & & $0.714^{\star \star *}$ & $0.607^{\star * *}$ & $0.595^{\star \star \star}$ & $0.650^{\star \star \star}$ & $0.663^{\star * *}$ \\
\hline Female*Lower sec. & & & & & $-0.292^{* * *}$ & $-0.208^{\star *}$ \\
\hline Female*Tertiary & & & & & -0.071 & -0.097 \\
\hline $\begin{array}{l}\text { Educational field: } \\
\text { Education }\end{array}$ & & & & & & \\
\hline Arts & & & $0.514^{\star * *}$ & $0.487^{\star \star *}$ & 0.275 & 0.273 \\
\hline Social Science & & & $0.196^{* *}$ & $0.143^{\star *}$ & 0.001 & 0.009 \\
\hline Science & & & $0.471^{* * *}$ & $0.414^{\star * *}$ & $0.228^{* * *}$ & $0.230^{\star * *}$ \\
\hline Engineering & & & $0.340^{* * *}$ & $0.295^{\star \star *}$ & $0.222^{\star \star}$ & $0.226^{\star *}$ \\
\hline Agriculture & & & $0.472^{* * *}$ & $0.392^{\star \star *}$ & $0.485^{\star \star *}$ & $0.482^{\star \star *}$ \\
\hline Health & & & $0.260^{\star * *}$ & $0.252^{\star \star *}$ & $0.422^{\star \star *}$ & $0.423^{\star \star *}$ \\
\hline Services & & & $0.659^{* * *}$ & $0.589^{\star \star *}$ & 0.224 & $0.214^{*}$ \\
\hline (Base: General) & & & $0.590^{* *}$ & $0.545^{\star * *}$ & $0.656^{\star * *}$ & $0.651^{* * *}$ \\
\hline Gender ${ }^{\star}$ Educational field: & & & & & & \\
\hline Female*Education & & & & & 0.234 & 0.248 \\
\hline Female*Arts & & & & & 0.187 & 0.171 \\
\hline Female*Social science & & & & & $0.244^{\star *}$ & $0.242^{* *}$ \\
\hline Female^Science & & & & & 0.141 & 0.131 \\
\hline Female*Engineering & & & & & $-0.351^{* * *}$ & $-0.334^{* * *}$ \\
\hline Female*Agriculture & & & & & $-0.399^{\star *}$ & $-0.389^{* *}$ \\
\hline Female*Health & & & & & $0.413^{* * *}$ & $0.432^{* * *}$ \\
\hline Female*Services & & & & & -0.195 & -0.182 \\
\hline Family status: & & & & & & \\
\hline $\begin{array}{l}\text { Has child } \\
\text { (Base: no child) }\end{array}$ & & & & $-0.402^{* * *}$ & $-0.397^{* * *}$ & -0.074 \\
\hline $\begin{array}{l}\text { Female*Family status } \\
\text { Educational } \\
\text { participation: }\end{array}$ & & & & & & $-0.590^{\star * *}$ \\
\hline $\begin{array}{l}\text { Participated in past } 4 \\
\text { weeks } \\
\text { (Base: did not participate) } \\
\text { Female*Educational }\end{array}$ & & & & $-0.646^{* * *}$ & $-0.642^{* \star *}$ & $-0.651^{* * *}$ \\
\hline participation & & & & & & -0.007 \\
\hline-2 log likelihood & 77082.06 & 73216.26 & 71515.82 & 66640.35 & 66508.46 & 66341.46 \\
\hline
\end{tabular}

Note: ${ }^{* * *} \mathrm{p}<.001,{ }^{* *} \mathrm{p}<.01$; country and country ${ }^{*}$ gender interactions are controlled for (see Appendix Table A1). 
Table 4 presents a binary logistic regression model predicting the chances of having obtained a first significant job by the time of the interview. A logistic regression model allows us to assess the effect of the explanatory variables on the log odds of obtaining a first significant job. A positive coefficient indicates increased chances of obtaining a first significant job while a negative coefficient indicates reduced chances. Thus, in Table 4 young women are less likely (0.439) to obtain a first significant job than young men who have spent a similar amount of time on the labour market (Model 1). This coefficient can be transformed into an odds ratio whereby young women are seen to be 0.6 times as likely to obtain a first significant job as young men.

Due to the shorter time span on the labour market observed in Finland, the Netherlands and Sweden, a variable representing time since leaving education (measured in months) is included in the model to correct for these differences. Young women are less likely to have obtained a job by the time of the interview than their male counterparts, even controlling for gender differences in educational level, field, family status and educational participation. As might be expected, educational level is strongly predictive of labour market integration with tertiary leavers 1.7 times more likely to have obtained a job than upper secondary leavers (see Model 2, Table 4). Those leaving at the lower secondary level are much less likely to have obtained a first significant job; this pattern is especially marked for young women (see Model 5).

Field of education is predictive of labour market integration (see Model 3). Leavers from all educational fields, especially health, services and education, have a higher chance of obtaining a job than those leaving from general tracks; the effect of having an Arts background is somewhat lower than for the other tracks. The effects of field are found to vary by gender. The returns to taking a social science/business or health course are higher for women than for men while the returns to taking an engineering or agriculture course are lower for women (Model 6).

\section{Figure 3 Country variation in gender differences in obtaining a first significant job}

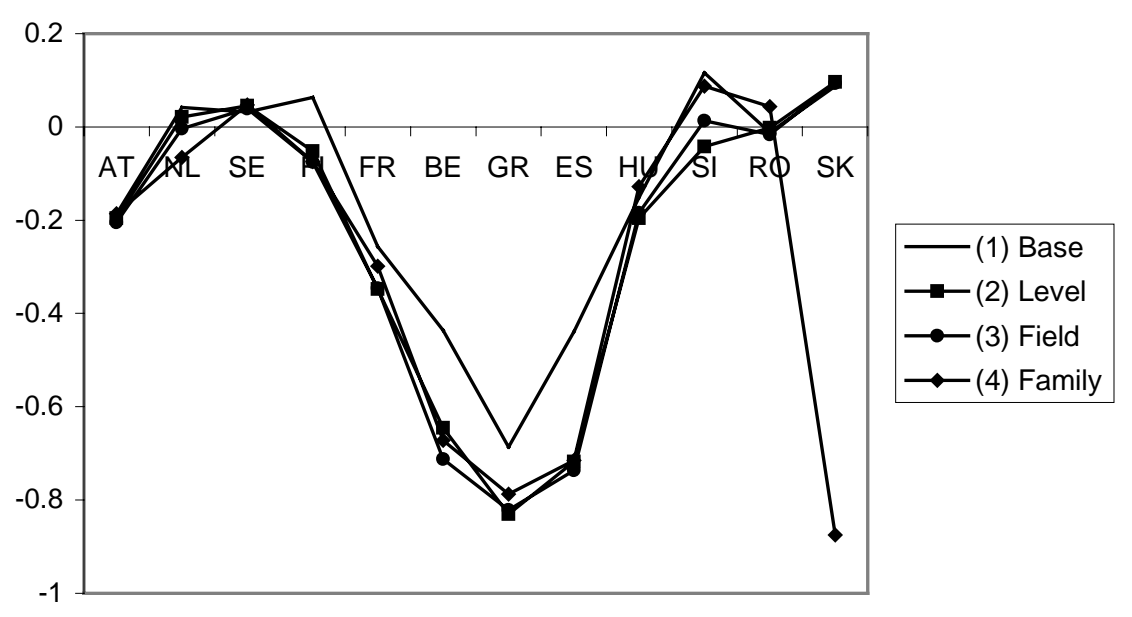


Young women who have a child are much less likely than other groups to have obtained a first significant job, perhaps because they have already withdrawn from the labour market (see below). Having taken part in an educational course in the previous four weeks is associated with lower chances of having integrated into the labour market; the effect is similar for males and females.

The pattern of labour market integration varies by country with the lowest levels found in the Southern (Spain and Greece) and two of the Eastern European countries (Slovakia and in particular Romania); the highest levels of integration are found in Belgium and Hungary (see Appendix Table A1). However, the concern of this paper is with the way in which gender differences in labour market integration may vary across countries. Figure 3 represents gender differences across countries with the four lines representing the size of these differences (1) without controls, (2) controlling for educational level, (3) controlling for level and field, and (4) controlling for level, field and family factors, respectively. The values are calculated from Appendix Table A1 ${ }^{4}$ Negative values indicate that women are less likely than men (all else being equal) to have obtained a first significant job. There is very little gender differentiation in labour market integration in the Scandinavian countries, the Netherlands and the Eastern European countries (with the exception of Slovakia). In contrast, there are very marked gender differences evident in Belgium and the Mediterranean countries. These differences are not explained by gender differences in educational level, field of education or family status. In fact, the gender gap increases when these factors are taken into account.

\section{Figure 4 Labour force participation rates by gender and country}

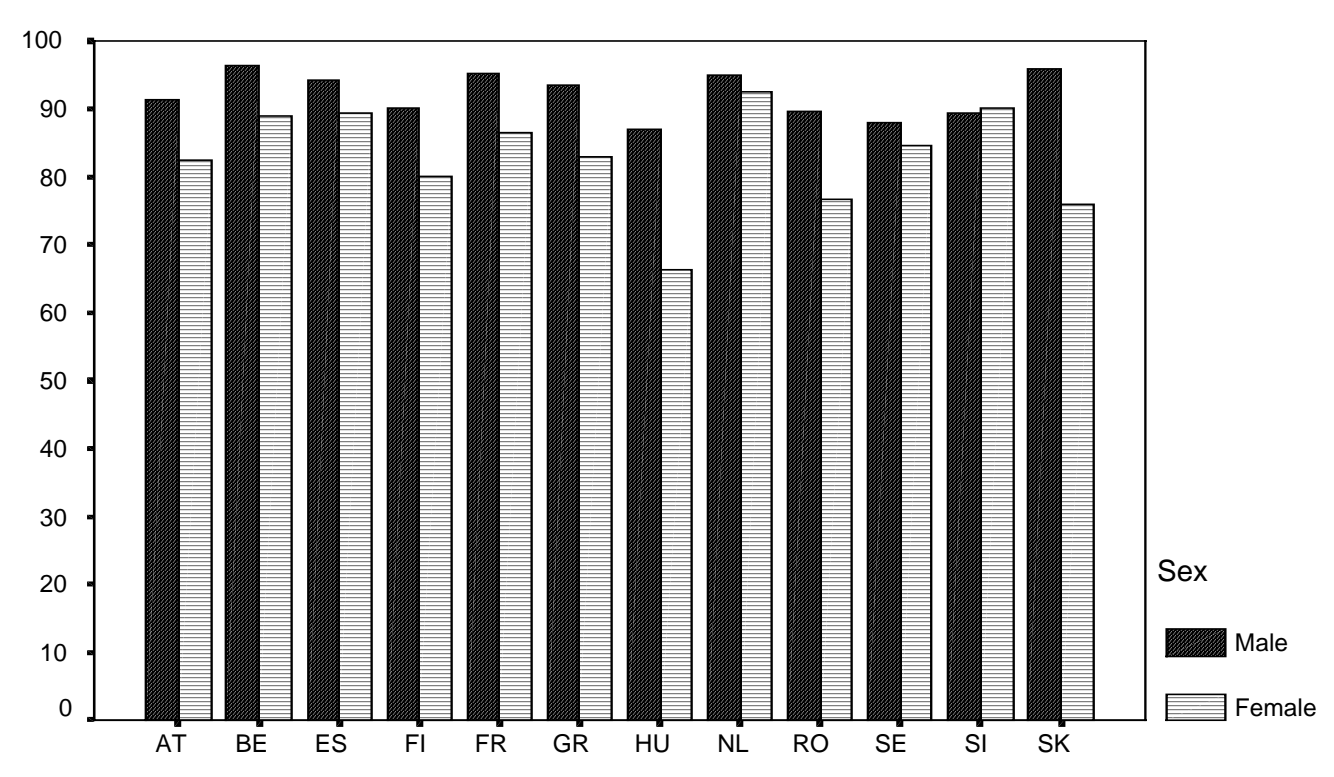

\footnotetext{
${ }^{4}$ Thus, the value for Austria in line 1 is calculated from the gender coefficient in Table $4(-0.439)$ added to the gender*country interaction term for Austria (0.252); this gives the gender difference for Austria.
} 
The relative disadvantage of young women in making the transition to a significant job found in some European countries (especially Belgium, Greece and Spain) may be due to a number of factors including gender differences in withdrawal from the labour force, gender differences in unemployment rates and gender differences in concentration in temporary/intermittent employment. These dimensions are explored in the remainder of this section.

Figure 4 illustrates labour force participation rates at the time of the interview by gender and country. ${ }^{5}$ With the exception of the Netherlands and Slovenia, male participation rates were significantly higher than female rates in all of the countries studied. The factors influencing labour force participation rates were analysed using a logistic regression model (see Table $5)$.

Female participation rates are found to be lower than male rates, even controlling for educational level and field (see Model 3). Participation is strongly associated with educational level with the lowest levels found among those with lower secondary education and the highest levels found among those with tertiary education. The positive effect of having a tertiary education is found to be somewhat less for women than for men (see Model 5). Leavers from all educational fields have a higher activity rate than those from general tracks. The effects vary somewhat by gender, however, with women who had taken engineering, agriculture or service courses having much lower participation rates than their male counterparts. Having a young child is associated with lower activity rates, but only for women. Similarly, having taken an educational course in the previous four weeks is associated with lower participation rates, indicating that a number of young people have returned to full-time education.

Figure 5 indicates cross-national variation in gender differences in labour force participation levels. Female labour force participation levels are lower than male levels across all European countries, with the exception of Slovenia. The greatest gender gaps are found in the Mediterranean countries, Hungary and the Northwestern countries (Belgium and France). In the case of Belgium, Greece and Spain, therefore, it would appear that the lower levels of labour market integration among young women (indicated above) are, at least in part, due to the greater tendency for young women to withdraw from the labour force.

Figure 6 indicates the unemployment rate (that is, the proportion of those in the labour force who were unemployed at the time of interview) by gender and country. In Spain, France, Greece and the Netherlands, female unemployment rates are significantly higher than those found among their male counterparts. The model presented in Table 6 indicates that young

\footnotetext{
${ }^{5}$ Those in military service are excluded for the purposes of this analysis.
} 
women are more likely to be unemployed than young men, even when gender differences in educational level and field are taken into account. ${ }^{6}$

Table 5 Logistic regression model of labour force participation

\begin{tabular}{|c|c|c|c|c|c|}
\hline & (1) & (2) & (3) & $(4)$ & (5) \\
\hline Intercept & $3.111^{* * *}$ & $3.349^{* * *}$ & $3.001^{* * *}$ & $3.394^{\star * *}$ & $-2.980^{\star * *}$ \\
\hline $\begin{array}{l}\text { Female } \\
\text { (Base: male) }\end{array}$ & $-0.801^{* * *}$ & $-1.035^{\star * *}$ & $-1.034^{\star \star *}$ & $-0.993^{* * *}$ & $-0.395^{\star * *}$ \\
\hline $\begin{array}{l}\text { Time since leaving } \\
\text { education (months) } \\
\text { Educational level: }\end{array}$ & -0.001 & $0.001^{* *}$ & 0.001 & $0.003^{* * *}$ & $0.004^{* * *}$ \\
\hline Lower secondary & & $-0.952^{* * *}$ & $-0.572^{* * *}$ & $-0.530^{* * *}$ & $-0.519^{* * *}$ \\
\hline $\begin{array}{l}\text { Tertiary } \\
\text { (Base: upper sec.) }\end{array}$ & & $0.742^{\star \star \star}$ & $0.649^{\star \star \star}$ & $0.678^{\star \star \star}$ & $0.876^{\star \star *}$ \\
\hline \multicolumn{6}{|l|}{$\begin{array}{l}\text { (Base: upper sec.) } \\
\text { Gender`Educational level: }\end{array}$} \\
\hline Female*Lower sec. & & & & & -0.049 \\
\hline Female*Tertiary & & & & & $-0.275^{\star *}$ \\
\hline \multicolumn{6}{|l|}{ Educational field: } \\
\hline Arts & & & $0.319^{* * *}$ & $0.225^{* *}$ & $0.338^{\star}$ \\
\hline Social Science & & & $0.604^{\star * *}$ & $0.505^{\star * *}$ & $0.512^{* \star *}$ \\
\hline Science & & & $0.289^{* * *}$ & $0.179^{*}$ & 0.132 \\
\hline Engineering & & & $0.497^{* * *}$ & $0.354^{* * *}$ & $0.666^{\star \star \star}$ \\
\hline Agriculture & & & $0.403^{* * *}$ & $0.327^{* * *}$ & $0.761^{* * *}$ \\
\hline Health & & & $0.559^{* * *}$ & $0.497^{\star * *}$ & $0.725^{\star * *}$ \\
\hline $\begin{array}{l}\text { Services } \\
\text { (Base: General) }\end{array}$ & & & $0.512^{\star \star \star}$ & $0.408^{* * *}$ & $0.687^{* * *}$ \\
\hline \multicolumn{6}{|l|}{$\begin{array}{l}\text { (Base: General) } \\
\text { Gender }{ }^{\star} \text { Educational field: }\end{array}$} \\
\hline Female*Education & & & & & 0.041 \\
\hline Female*Arts & & & & & -0.183 \\
\hline Female*Social science & & & & & -0.059 \\
\hline Female ${ }^{\star}$ Science & & & & & 0.137 \\
\hline Female*Engineering & & & & & $-0.636^{* * *}$ \\
\hline Female*Agriculture & & & & & $-0.656^{* *}$ \\
\hline Female*Health & & & & & -0.288 \\
\hline Female*Services & & & & & $-0.365^{\star}$ \\
\hline \multicolumn{6}{|l|}{ Family status: } \\
\hline $\begin{array}{l}\text { Has child } \\
\text { (Base: no child) }\end{array}$ & & & & $-1.070^{* * *}$ & -0.085 \\
\hline $\begin{array}{l}\text { Female }{ }^{\star} \text { Family status } \\
\text { Educational participation: }\end{array}$ & & & & & $-1.420^{* \star *}$ \\
\hline $\begin{array}{l}\text { Participated in past } 4 \text { weeks } \\
\text { (Base: did not participate) }\end{array}$ & & & & $-1.610^{\star \star *}$ & $-2.179^{* * *}$ \\
\hline $\begin{array}{l}\text { Female Educational } \\
\text { participation }\end{array}$ & & & & & $0.929^{* * *}$ \\
\hline-2 log likelihood & 50340.76 & 47638.21 & 46624.37 & 41062.23 & 40228.95 \\
\hline
\end{tabular}

Note: ${ }^{* *} \mathrm{p}<.001,{ }^{* *} \mathrm{p}<.01$; country and country ${ }^{*}$ gender interactions are controlled for (see Appendix Table A2).

${ }^{6}$ Family status and educational participation are not included in this model because they are expected to influence decisions about remaining in the labour market rather than 'success' within the labour market per se. 
Figure 5 Country variation in gender differences in labour force participation

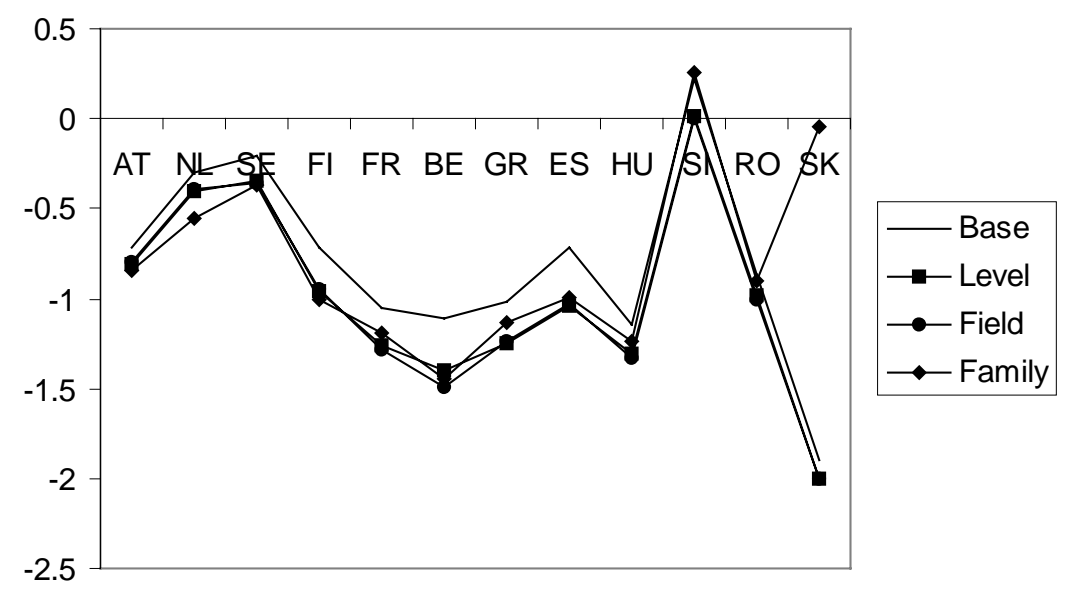

Figure 6 Unemployment rate by gender and country

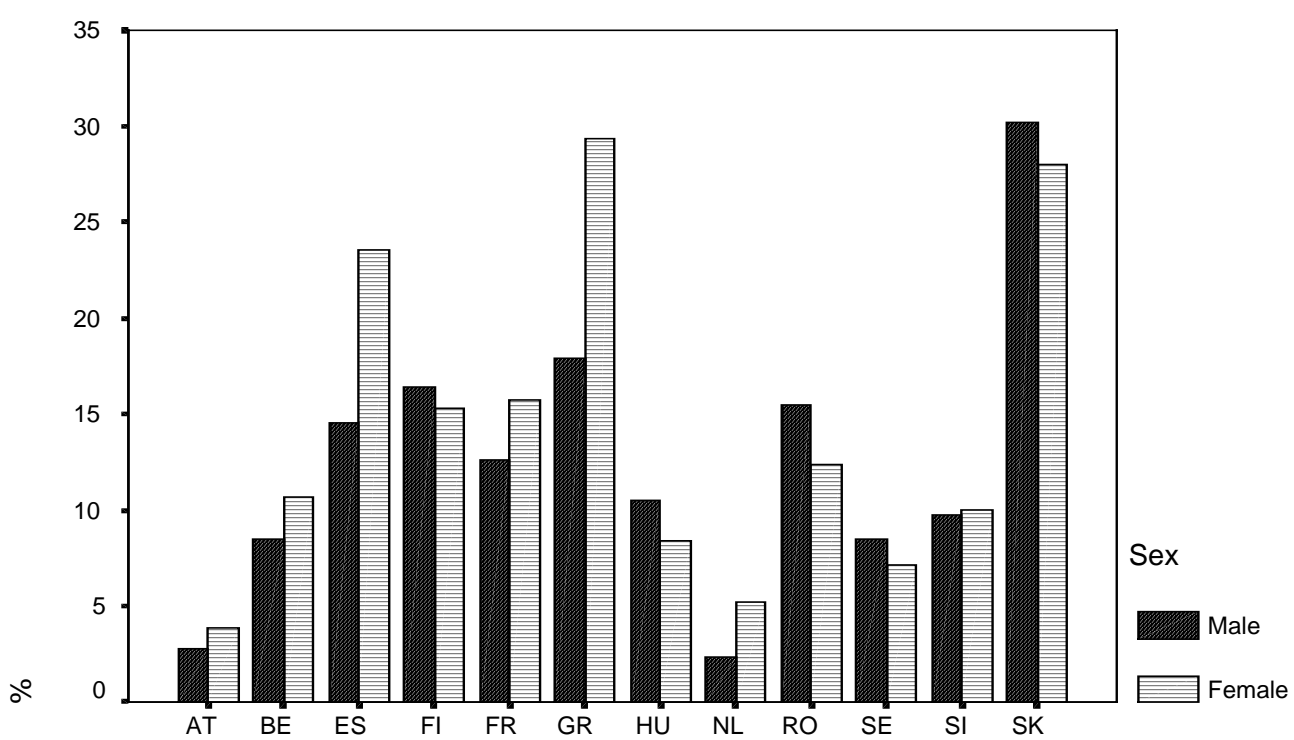

Unemployment is found to decrease with amount of time since leaving education. Lower secondary leavers have the highest unemployment rates while the lowest rates are found among tertiary leavers; the pattern is similar for males and females. Model 3 indicates that unemployment rates are highest among those with an arts education and lowest among those who have taken health/welfare courses. On closer inspection, the pattern is found to vary by gender. An arts or social science background is associated with higher unemployment for males only while women with an engineering background have higher unemployment rates than their male counterparts (Model 4). 
Table 6 Logistic regression model of current unemployment

\begin{tabular}{|c|c|c|c|c|}
\hline & (1) & (2) & (3) & $(4)$ \\
\hline Intercept & $-1.131^{* * *}$ & $-1.056^{\star \star \star}$ & $-1.005^{\star \star \star}$ & $-1.035^{\star \star *}$ \\
\hline $\begin{array}{l}\text { Female } \\
\text { (Base: male) }\end{array}$ & $0.563^{* * *}$ & $0.763^{* * *}$ & $0.762^{\star * *}$ & $0.834^{* * *}$ \\
\hline $\begin{array}{l}\text { Time since leaving } \\
\text { education (months) } \\
\text { Educational level: }\end{array}$ & $-0.011^{* * *}$ & $-0.013^{* * *}$ & $-0.013^{* * *}$ & $-0.013^{* * *}$ \\
\hline Lower secondary & & $0.536^{\star \star *}$ & $0.493^{\star * *}$ & $0.518^{\star \star \star}$ \\
\hline \multicolumn{5}{|l|}{$\begin{array}{l}\text { (Base: upper sec.) } \\
\text { GenderEducational level: }\end{array}$} \\
\hline Female*Lower sec. & & & & -0.053 \\
\hline \multicolumn{5}{|l|}{ Educational field: } \\
\hline Education & & & -0.057 & 0.273 \\
\hline Arts & & & $0.194^{\star *}$ & $0.554^{\star \star \star}$ \\
\hline Social Science & & & -0.010 & $0.198^{\star \star \star}$ \\
\hline Science & & & -0.086 & 0.022 \\
\hline Engineering & & & -0.087 & -0.157 \\
\hline Agriculture & & & 0.010 & -0.127 \\
\hline Health & & & $-0.243^{* * *}$ & 0.001 \\
\hline Services & & & -0.043 & -0.021 \\
\hline (Base: General) & & & & \\
\hline \multicolumn{5}{|l|}{ Gender ${ }^{\star}$ ducational field: } \\
\hline Female*Education & & & & -0.427 \\
\hline Female*Arts & & & & $-0.542^{\star * *}$ \\
\hline Female*Social science & & & & $-0.304^{* *}$ \\
\hline Female*Science & & & & -0.202 \\
\hline Female*Engineering & & & & $0.414^{* * *}$ \\
\hline Female*Agriculture & & & & 0.391 \\
\hline Female*Health & & & & -0.311 \\
\hline Female*Services & & & & -0.037 \\
\hline-2 log likelihood & 52229.368 & 50393.929 & 49475.107 & 49371.245 \\
\hline
\end{tabular}

Note: ${ }^{\star * \star} \mathrm{p}<.001,{ }^{* \star} \mathrm{p}<.01$; country and country ${ }^{*}$ gender interactions are controlled for (see Appendix Table A3).

Female unemployment rates are the same as, or lower than, male rates in the Eastern European and Scandinavian countries, all else being equal (see Figure 7). In contrast, female rates are much higher than male rates in the Netherlands, Austria, France, Belgium and the Mediterranean countries. In Belgium and the Mediterranean countries, gender differences actually increase when educational level and field is taken into account. In overall terms, the lower chances of labour market integration found among young women reflect not only lower labour force participation rates but also higher rates of unemployment among those who remain within the labour force. The pattern may also be explained by gender differences in the proportion in intermittent employment. Unfortunately, complete work history information indicating the prevalence of intermittent employment is not available from the ad hoc module. However, young women in Greece and Belgium are more likely to be on a temporary contract at the time of the interview than their male counterparts (analysis not shown here). 
Figure 7 Country variation in gender differences in current unemployment

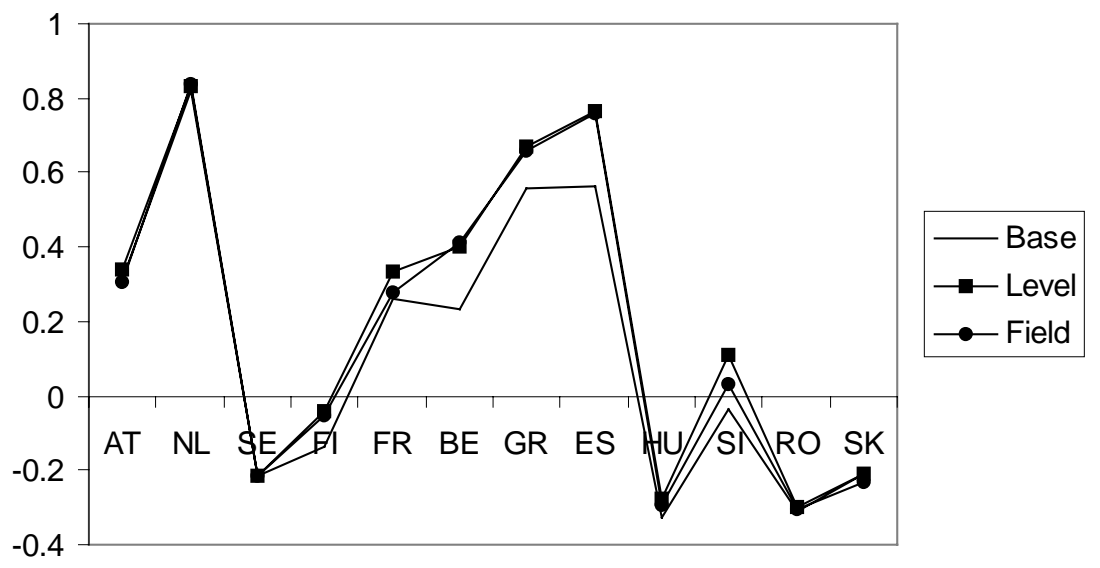

\section{Occupational segregation by gender}

In all of the countries, the distribution across occupational groups differs significantly for males and females. As with educational field, occupational groups were divided into 'femaleintensive', 'mixed' and 'male-intensive' categories, adjusting the cut-offs for the representation of women in the workforce in each country. In all countries, senior managerial, craft and machine operator jobs tend to be dominated by men while females tend to predominate in clerical and service jobs (see Table 7). It should be noted that these broad categories include jobs with very different gender profiles.

Table 7 Female-intensity of different occupational groups

\begin{tabular}{|c|c|c|c|c|c|c|c|c|c|}
\hline & $\begin{array}{c}\text { Senior } \\
\text { managers }\end{array}$ & $\begin{array}{l}\text { Profess- } \\
\text { ional }\end{array}$ & Technical & $\begin{array}{l}\text { Clerical } \\
\text { workers }\end{array}$ & $\begin{array}{l}\text { Service } \\
\text { workers }\end{array}$ & $\begin{array}{l}\text { Agricultural } \\
\text { workers }\end{array}$ & $\begin{array}{c}\text { Craft } \\
\text { workers }\end{array}$ & $\begin{array}{l}\text { Machine } \\
\text { operators }\end{array}$ & $\begin{array}{l}\text { Elementary } \\
\text { occupations }\end{array}$ \\
\hline AT & $M$ & $\mathrm{~N}$ & $\mathrm{~N}$ & $\mathrm{~F}$ & $\mathrm{~F}$ & M & M & $\mathrm{M}$ & $\mathrm{N}$ \\
\hline $\mathrm{NL}$ & $M$ & $\mathrm{~N}$ & $\mathrm{~N}$ & $F$ & $\mathrm{~F}$ & . & M & (M) & $\mathrm{N}$ \\
\hline SE & $\mathrm{M}$ & $\mathrm{N}$ & $\mathrm{N}$ & $\mathrm{F}$ & $\mathrm{F}$ & . & M & M & $\mathrm{N}$ \\
\hline $\mathrm{FI}$ & $M$ & $\mathrm{~F}$ & $\mathrm{~N}$ & $F$ & $\mathrm{~F}$ & $\mathrm{~N}$ & M & M & $\mathrm{N}$ \\
\hline FR & M & $\mathrm{N}$ & $\mathrm{N}$ & $\mathrm{F}$ & $\mathrm{F}$ & $\mathrm{M}$ & $\mathrm{M}$ & M & $\mathrm{N}$ \\
\hline $\mathrm{BE}$ & M & $\mathrm{F}$ & $\mathrm{N}$ & $\mathrm{F}$ & $\mathrm{F}$ & $\mathrm{M}$ & M & $\mathrm{M}$ & $\mathrm{N}$ \\
\hline GR & $\mathrm{M}$ & $\mathrm{F}$ & $\mathrm{F}$ & $\mathrm{F}$ & $\mathrm{N}$ & $M$ & $\mathrm{M}$ & M & M \\
\hline ES & $\mathrm{M}$ & $\mathrm{F}$ & $\mathrm{F}$ & $\mathrm{F}$ & $\mathrm{F}$ & M & M & $\mathrm{M}$ & M \\
\hline $\mathrm{HU}$ & $\mathrm{M}$ & $\mathrm{F}$ & $\mathrm{F}$ & $\mathrm{F}$ & $\mathrm{F}$ & $\mathrm{M}$ & $M$ & $\mathrm{~N}$ & $\mathrm{M}$ \\
\hline SI & M & $\mathrm{F}$ & $\mathrm{N}$ & $\mathrm{F}$ & $\mathrm{F}$ & $(\mathrm{N})$ & M & $\mathrm{M}$ & (M) \\
\hline RO & $\mathrm{M}$ & $\mathrm{N}$ & $\mathrm{F}$ & $\mathrm{F}$ & $\mathrm{F}$ & $\mathrm{N}$ & $\mathrm{M}$ & $\mathrm{M}$ & $\mathrm{M}$ \\
\hline SK & $M$ & $\mathrm{~N}$ & $F$ & $F$ & $F$ & $M$ & M & $M$ & M \\
\hline
\end{tabular}

Note: due to small numbers, the army category is not included in this table. 
There has been some debate about the appropriate measure of occupational segregation (see, for example, Siltanen, Jarman and Blackburn, 1995; Kalter, 2000). Here indices of dissimilarity are used and were calculated for ISCO 1-digit, 2-digit and 3-digit occupational groupings. ${ }^{7}$ Table 8 indicates that the level of segregation is found to be higher when more detailed occupational groups are used; this reflects the fact that broader occupational groups often contain occupations with very different gender profiles. The three measures are significantly correlated with each other $(r=0.7$ between 1 -digit and 2-digit measures and $r=0.5$ between 1-digit and 3-digit measures), indicating that segregation tends to be greater in certain countries, regardless of the measure used.

Table 8 Occupational segregation by gender in first significant job

\begin{tabular}{lccc}
\hline & 1-digit & 2-digit & 3-digit \\
\hline Austria & & & \\
Netherlands & 45.5 & 56.8 & 64.3 \\
Sweden & 32.3 & 38.6 & 52.9 \\
Finland & 30.8 & 40.9 & 51.4 \\
France & 35.6 & 51.2 & 56.1 \\
Belgium & 37.3 & 47.5 & 51.7 \\
Greece & 31.6 & 44.3 & 51.6 \\
Spain & 36.1 & 41.2 & 48.8 \\
Hungary & 42.1 & 47.5 & 53.7 \\
Slovenia & 37.7 & 49.0 & 58.5 \\
Romania & 34.9 & 42.3 & 57.9 \\
Slovakia & 36.4 & n.a. & n.a. \\
& 37.6 & 55.4 & 66.1 \\
\hline
\end{tabular}

Gender segregation is found to be highest in Austria ${ }^{8}$, Hungary, Slovakia and France, and lowest in Sweden, Belgium and the Netherlands. It had been hypothesised that occupational segregation would be greatest in the countries with the highest levels of educational segregation by gender with young people being 'pre-sorted' into gender-typed occupations on the basis of their educational experiences (see Borghans and Groot, 1999). Figure 8 shows the measures of segregation for both occupation and education (in the latter case, combining segregation measures at upper secondary and tertiary levels). In the case of occupation, the measure based on the 3-digit ISCO classification is used; for Romania, the 1-digit measure is used because of the lack of information on more detailed occupational groupings. It is apparent that educational and occupational segregation are interrelated at the country level (with a correlation of $r=+0.7$ ) with Austria and Slovenia

${ }^{7}$ These were calculated by summing the absolute differences in the proportion of males and females in each occupational group and dividing the total by two.

${ }^{8}$ The data for Austria are not fully comparable with the other countries since they relate to current job. However, analysis does reveal Austria as an outlier in segregation terms. 
showing the highest levels of segregation and Romania and Greece showing the lowest levels of segregation. The location of the Netherlands is somewhat surprising given previous research on the strong levels of gender segregation within the educational system (see Borghans and Groot, 1999; Smyth, 2001). It may be that the broad groupings of educational field available in the ad hoc module obscure some of the segregation happening at a more detailed level of aggregation.

Figure 8 Measures of educational and occupational segregation by country

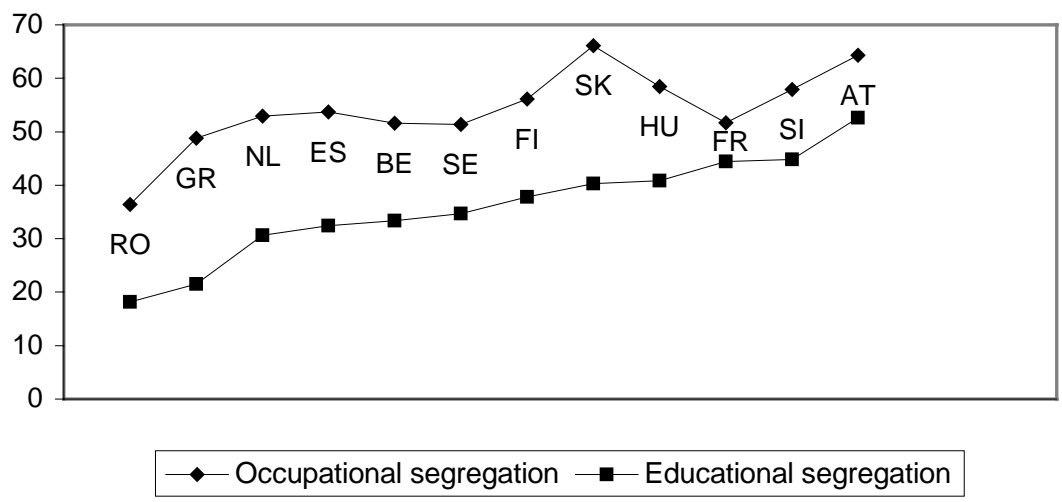

The purpose of this paper is not to examine the 'matching' between educational field and occupational group (see Wolbers, 2002) but it is useful to explore the ways in which participation in a gendered educational track influences the type of occupation entered. The gender-typing of educational field (general, male-intensive, mixed and female-intensive) is significantly related to the gender-typing of first significant job ${ }^{9}$ in all of the countries considered. For the purposes of this and subsequent analysis, those leaving from lower secondary education are assigned to general tracks because of the considerable crossnational variation in the existence of track differentiation at this level.

Table 9 presents a multinomial logistic regression equation predicting entry to predominantly male and predominantly female occupations relative to entry to mixed jobs. Young women are significantly less likely to enter predominantly male jobs and more likely to enter predominantly female jobs, even controlling for gender and educational field. Thus not all gender segregation is attributable to educational segregation with gender continuing to have a direct effect on the 'sorting' of young men and women into gendered jobs. Having a lower secondary education increases the chances of entering a male job and reduces the chances of entering a female job; this is likely to reflect the strongly male profile of manual jobs. Having

${ }^{9}$ The measure of gender-typing of occupation is based on 1-digit ISCO classifications because of the possible influence of small sample sizes at the more detailed level of occupational aggregation. 
a tertiary education increases the chances of entering a mixed occupation. Females with a tertiary education have reduced chances of entering female occupations.

Leavers from a male track are much more likely to enter a male track and leavers from a female track are much more likely to enter a female track. However, there is also a considerable amount of movement from mixed tracks into gender-typed occupations. This may be due to the fact that occupational segregation is somewhat stronger than educational segregation (see Figure 8) so that there is more room for potential movement from mixed tracks into gender-typed jobs. There is no evidence that the effect of educational field differs for men and women; the exception is a greater tendency to enter male occupations among women from mixed tracks.

Table 9 Multinomial logit model of gender-typing of first significant job (contrasted against entry to mixed occupations)

\begin{tabular}{|c|c|c|}
\hline & Male & Female \\
\hline Intercept & $1.087^{* * *}$ & $1.024^{\star * *}$ \\
\hline Female & $-0.614^{* * *}$ & $0.922^{* * *}$ \\
\hline \multirow{2}{*}{\multicolumn{3}{|c|}{$\begin{array}{l}\text { (Base: male) } \\
\text { Educational level: }\end{array}$}} \\
\hline & \multicolumn{2}{|c|}{ Educational level: } \\
\hline Lower secondary & $0.596^{\star \star \star}$ & $-0.355^{\star * *}$ \\
\hline Tertiary & $-2.177^{\star * *}$ & $-0.547^{\star \star *}$ \\
\hline \multicolumn{3}{|l|}{ (Base: upper secondary) } \\
\hline \multicolumn{3}{|l|}{ Gender*Educational level: } \\
\hline Female*Lower sec. & $0.420^{* * *}$ & 0.267 \\
\hline Female ${ }^{\star}$ Tertiary & 0.106 & $-0.663^{\star * *}$ \\
\hline \multicolumn{3}{|l|}{ Educational field: } \\
\hline Male-dominated & $1.264^{\star \star *}$ & $0.276^{\star * *}$ \\
\hline Mixed & $1.268^{\star * *}$ & $1.244^{\star \star \star}$ \\
\hline Female-dominated & 0.083 & $1.023^{* * *}$ \\
\hline (Base: General) & & \\
\hline \multicolumn{3}{|l|}{ Gender*Educational field: } \\
\hline Female*Male-dominated course & 0.251 & -0.107 \\
\hline Female*Mixed course & $0.494^{* * *}$ & 0.256 \\
\hline Female*Female-dominated course & 0.130 & -0.089 \\
\hline-2 Log likelihood & \multicolumn{2}{|c|}{7108.598} \\
\hline
\end{tabular}

Note: ${ }^{* * *} p<.001,{ }^{* *} p<.01 ;$ country and country ${ }^{*}$ gender interactions are controlled for (see Appendix Table A4).

It was hypothesised above that in track-differentiated systems, gender segregation in labour market outcomes will tend to be mediated by the type of course taken whereas direct gender effects on occupational allocation should be stronger in general than in trackdifferentiated systems. It can be quite difficult to interpret country and country-gender interaction coefficients in multinomial logit models (see Appendix Table A4). For the purposes of comparison, therefore, the predicted probabilities of leavers from maledominated courses entering male-dominated occupations (termed 'male-male' in Figure 9) 
and of leavers from female-dominated courses entering female-dominated occupations (termed 'female-female' in Figure 9) were calculated for Austria (a country with a high level of educational and occupational segregation by gender), Greece and Romania (countries with low levels of educational and occupational segregation by gender). It is apparent that in Austria there are strong gender differences in occupational destination, even among those who have taken similar educational tracks. Of those who have taken male-dominated courses, all else being equal, over seventy per cent of males but less than a third of females enter male-dominated occupations. Of those who have taken female-dominated courses in Austria, almost sixty per cent of young women enter female-dominated jobs but this is the case for only a third of young men. Thus, higher levels of occupational segregation in the Austrian youth labour market reflect not only marked gender differences in the type of courses taken but marked differences in occupational outcomes for women and men taking 'male' (or 'female') tracks.

Gender differences in occupational outcomes are also apparent among those taking male and female tracks in the lower segregation countries of Greece and Romania. However, in some instances gender differentiation is less marked than in the Austrian situation; for example, a relatively high proportion (57\%) of young women taking male courses in Romania subsequently enter male-dominated occupations. In overall terms, occupational segregation in the youth labour market tends to reflect both 'presorting' into different educational fields and 'post-sorting' into different occupational destinations among those in the same field of education. The degree to which this takes place is likely to reflect the complexity of institutional, social and economic factors operating at the country level.

Figure 9 Predicted probabilities of entering male and female-dominated occupations for selected countries (upper secondary leavers)

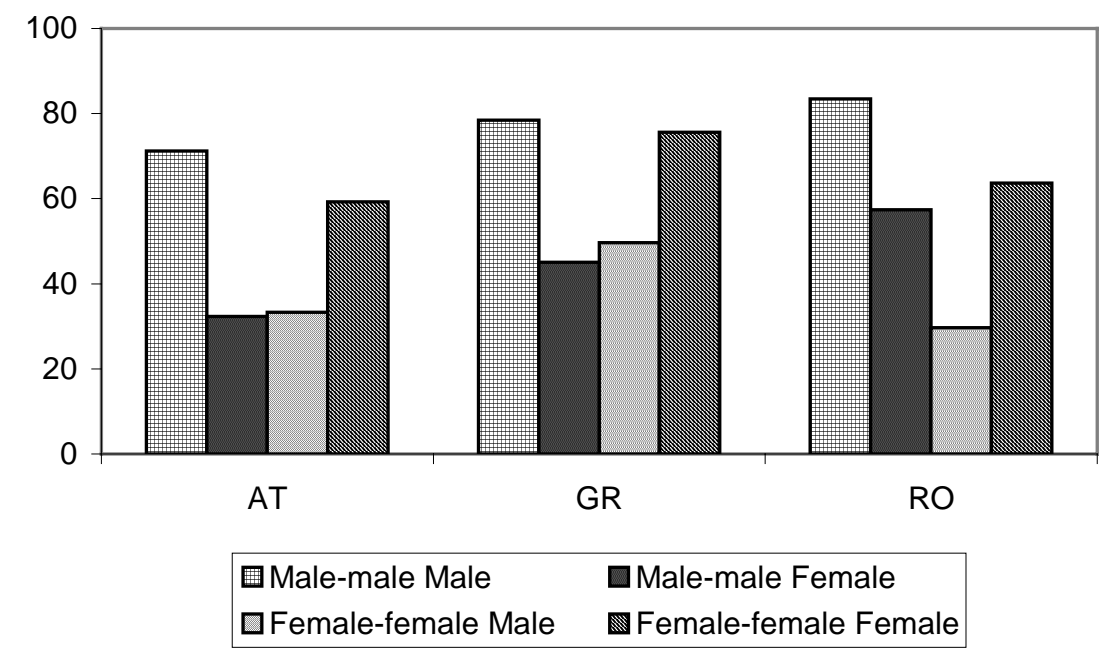




\section{Occupational status and gender differentiation}

ISEI occupational status scores were assigned to occupational groups. Figure 10 indicates varying patterns of gender differences in occupational status across countries. In all countries except the Netherlands, women have higher average status scores than men. This may be related to the greater concentration of women in non-manual jobs which tend to have higher prestige scores than manual occupations. It should be noted that higher occupational status scores do not necessarily translate into higher pay and mobility opportunities for women (see Smyth, 2001). Given that women tend to have higher educational attainment levels than men (see above), gender differences in educational level and field may also account for variation in occupational status.

Figure 10 Occupational status of first significant job by gender and country

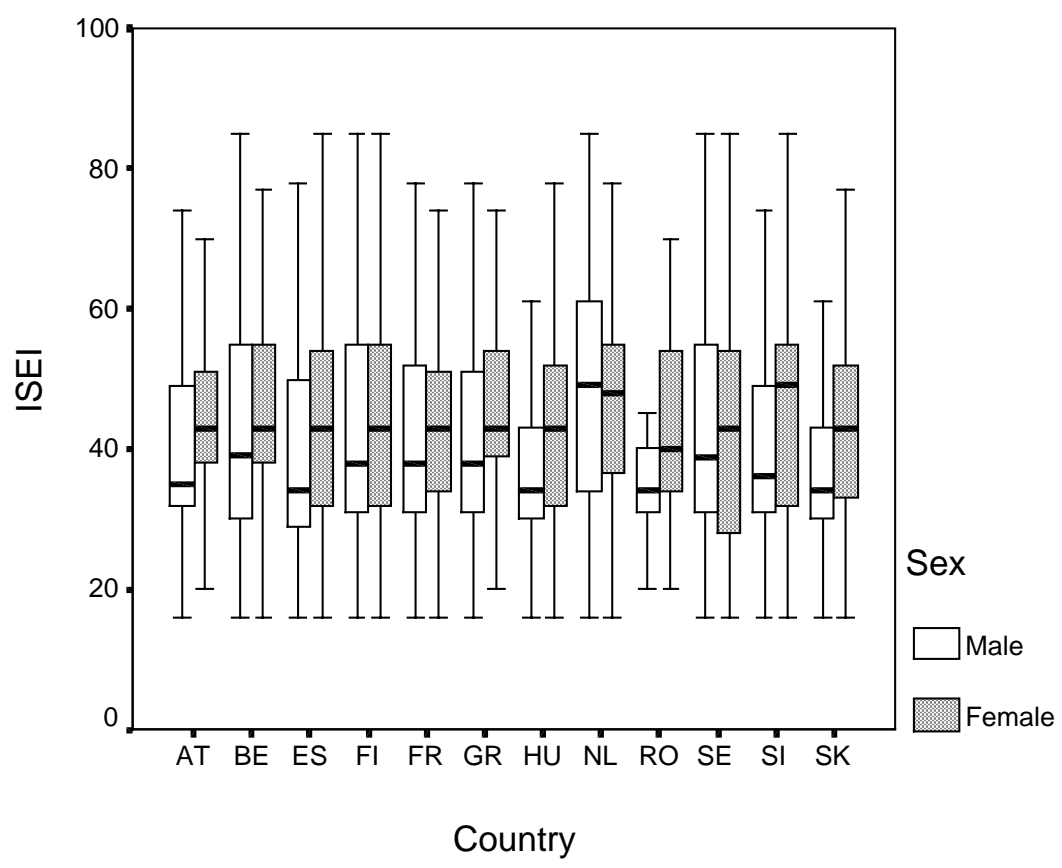

Table 10 presents a model predicting the occupational status of the first significant job. Young women are found to enter higher status occupations, controlling for their educational level (Model 2). Lower secondary leavers enter lower status occupations, and tertiary leavers enter higher status occupations, than those with upper secondary education. However, the status returns to tertiary education are significantly lower for women than for men. Educational field is strongly predictive of occupational status (see Model 3). Those with agriculture, service and engineering backgrounds enter the lowest status occupations with the highest status levels found among those with science backgrounds. However, the effect of educational field is found to vary by gender (see Figure 11). In general, women achieve higher occupational status than men who had studied the same type of course, with the exception of health/welfare courses. For men, the status returns are highest for health 
Table 10 Linear regression model of occupational status of first job

(1) (2)

\begin{tabular}{|c|c|c|c|c|}
\hline $\begin{array}{l}\text { Intercept } \\
\text { Female } \\
\text { (Base: male) }\end{array}$ & $\begin{array}{c}39.111 \\
6.074^{* * *}\end{array}$ & $\begin{array}{c}34.084 \\
2.461^{\star \star \star *}\end{array}$ & $\begin{array}{c}35.214 \\
1.563^{\star \star \star}\end{array}$ & $\begin{array}{c}34.796 \\
2.665^{\star \star \star}\end{array}$ \\
\hline $\begin{array}{l}\text { Educational level: } \\
\text { Lower secondary } \\
\text { Tertiary } \\
\text { (Base: upper secondary) }\end{array}$ & & $\begin{array}{l}-5.445^{\star \star \star} \\
17.887^{\star \star \star}\end{array}$ & $\begin{array}{l}-6.301^{\star * *} \\
16.332^{\star * *}\end{array}$ & $\begin{array}{l}-6.306^{\star * *} \\
18.249^{\star * *}\end{array}$ \\
\hline $\begin{array}{l}\text { Gender*Educational level: } \\
\text { Female*Lower sec. } \\
\text { Female*Tertiary }\end{array}$ & & & & $\begin{array}{l}-0.114 \\
-4.045^{\text {***}}\end{array}$ \\
\hline $\begin{array}{l}\text { Educational field: } \\
\text { Education } \\
\text { Arts } \\
\text { Social Science } \\
\text { Science } \\
\text { Engineering } \\
\text { Agriculture } \\
\text { Health } \\
\text { Services } \\
\text { (Base: General) }\end{array}$ & & & 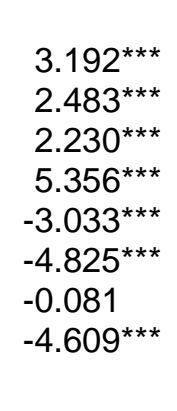 & $\begin{array}{c}0.924 \\
0.889 \\
0.834 \\
4.501^{\star *} \\
-3.595^{\star * \star} \\
-6.832^{\star * *} \\
5.532^{* \star *} \\
-4.359^{\star * \star}\end{array}$ \\
\hline $\begin{array}{l}\text { Gender*Educational field: } \\
\text { Female*Education } \\
\text { Female*Arts } \\
\text { Female } \\
\text { Female }{ }^{\star} \text { Social science } \\
\text { Female }{ }^{\star} \text { Engineering } \\
\text { Female*Agriculture } \\
\text { Female*Health } \\
\text { Female*Services }\end{array}$ & & & & $\begin{array}{l}4.036^{\star * *} \\
3.123^{\star * *} \\
2.436^{\star * *} \\
1.638^{\star *} \\
1.609^{* * *} \\
5.683^{\star * *} \\
-6.257^{\star * *} \\
-0.439 \\
\end{array}$ \\
\hline Adjusted R Square & 0.029 & 0.361 & 0.388 & 0.394 \\
\hline
\end{tabular}

Note: ${ }^{* * *} \mathrm{p}<.001,{ }^{* *} \mathrm{p}<.01$; country and country ${ }^{*}$ gender interactions are controlled for (see Appendix Table A5).

Figure 11 Predicted returns to various fields of education (controlling for level)

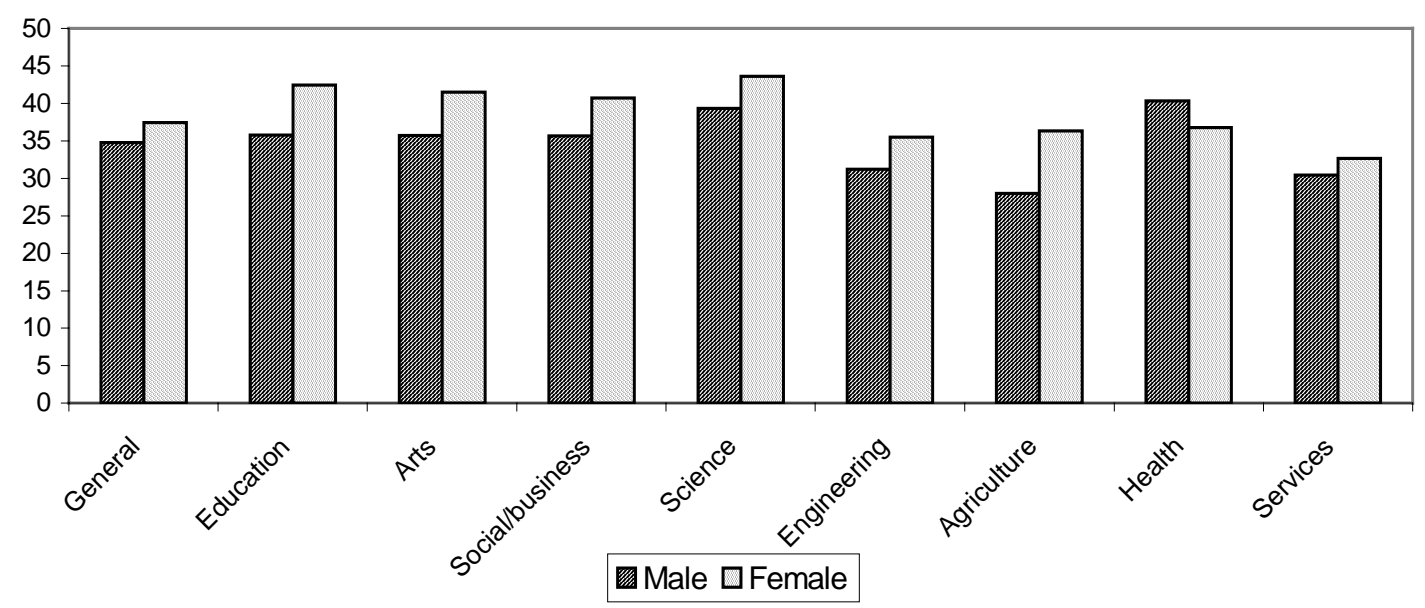


and science courses and lowest for engineering and agriculture courses. For women, the status returns are highest for science, education, arts and social science/business courses.

A good deal of young women's advantage in occupational status terms is due to their higher educational levels and the type of courses they study; in other words, the gap between male and female scores is reduced when educational level and field of education are taken into account (see Figure 12). The gender gap in occupational status levels is found to vary by country with the greatest advantage to young women found in the Mediterranean and Eastern European countries.

Figure 12 Country variation in gender differences in occupational status

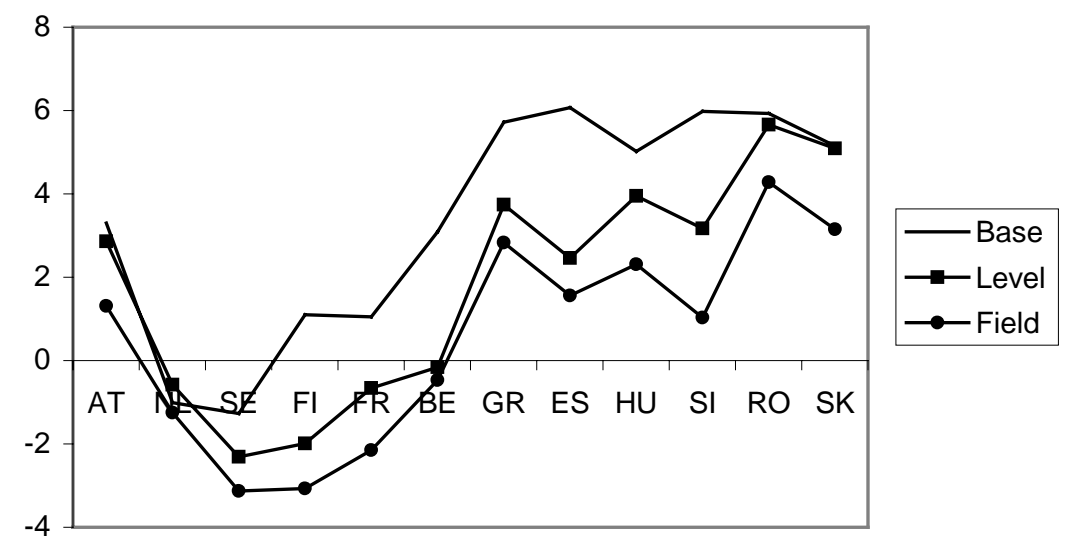

\section{Occupational upgrading}

Analyses were carried out to determine whether respondents had experienced an upgrading in occupational status levels between their first significant and current jobs. Young people who were in a higher status occupation in their current job than in their first significant job were considered as having experienced an occupational upgrading, regardless of the 'size' of this shift. Figure 13 refers only to those who changed jobs between their first significant job and their job at the time of the interview. In all of the countries examined, a considerable proportion of young people who had changed jobs had experienced occupational upgrading, although there is some variation by country in the overall levels. With the exception of the Netherlands, women are less likely to have experienced occupational upgrading than men; this difference is statistically significant in Spain, Finland, France, Greece, Hungary and Slovakia.

The factors influencing occupational upgrading are explored in Table 11. Even controlling for educational level and field, young women are less likely to achieve occupational upgrading than their male counterparts. Tertiary education leavers have a greater chance of upgrading 


\section{Figure 13 Occupational upgrading by gender and country}

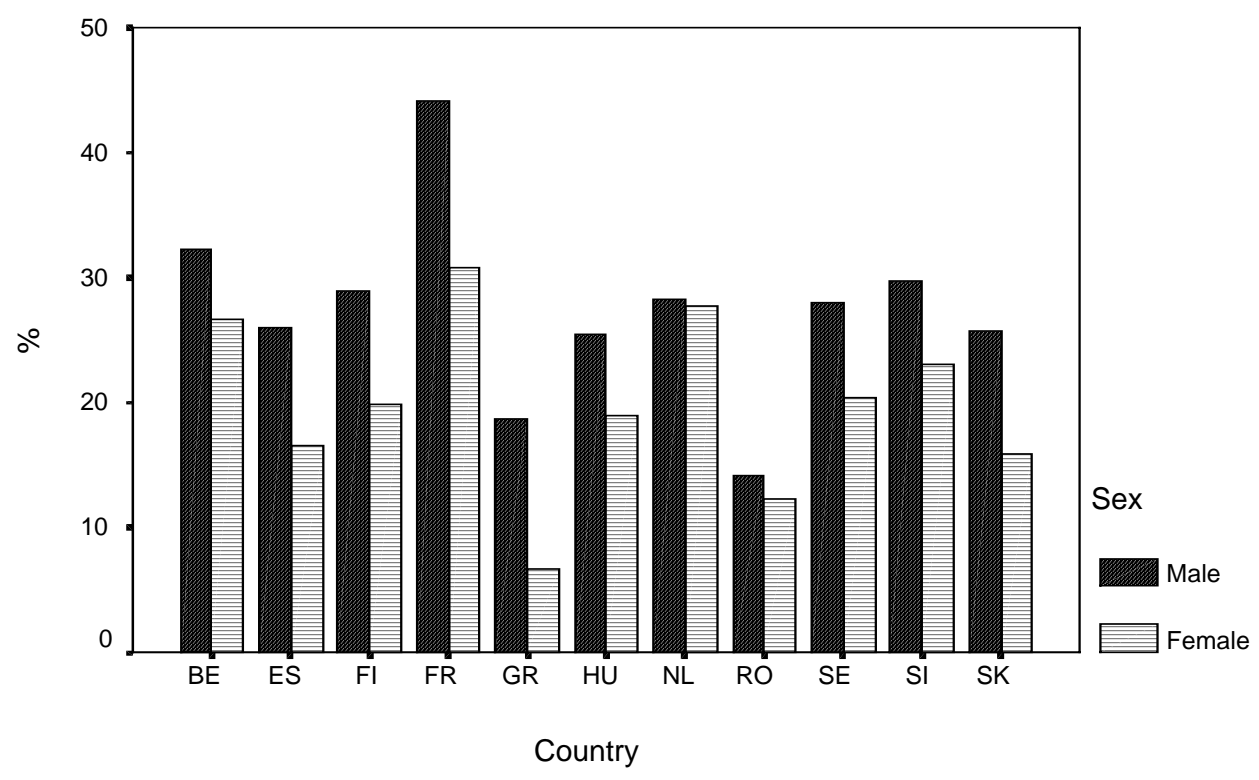

while lower secondary leavers have the lowest chances of being upgraded(see Table 11). However, tertiary education does not translate into occupational upgrading to the same extent for women as for men. The chances of upgrading are lowest for those who had taken education, health, agriculture and services courses.

Experience of occupational upgrading is found to be influenced by young people's history within the labour market (see Model 4, Table 11). Those who entered a first job with higher status levels are less likely to be upgraded subsequently, perhaps because of a ceiling effect in higher status occupations. In addition, upgrading one's educational level increases the chances of occupational upgrading. All else being equal, women remain less likely to achieve upgrading than men.

Figure 14 Country variation in gender differences in occupational upgrading

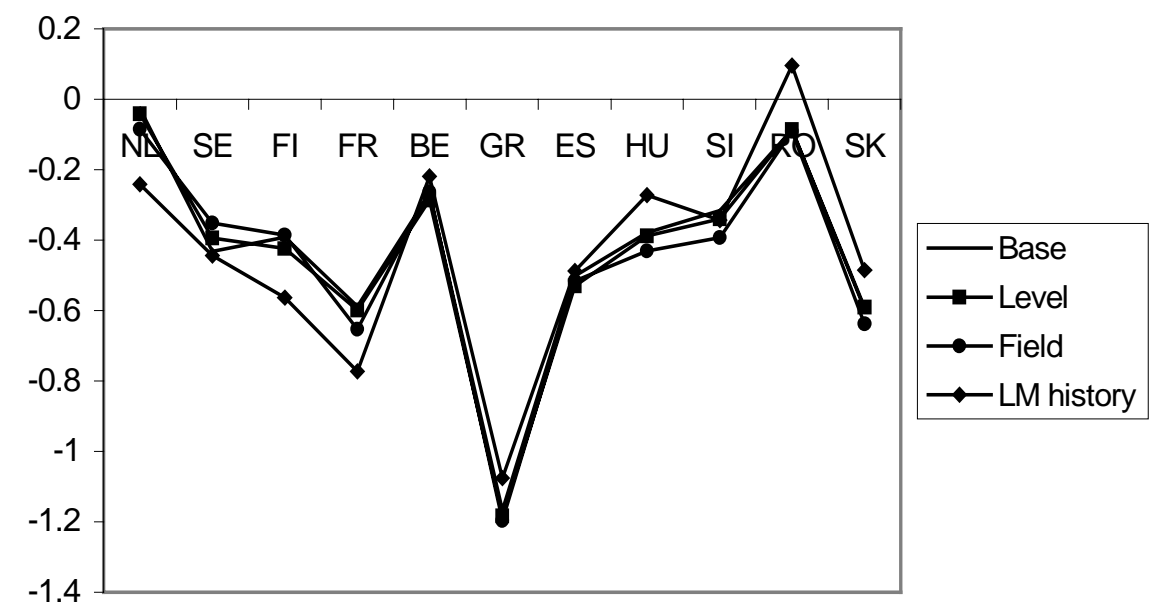


There is some cross-national variation in gender differences in occupational upgrading (see Figure 14). The biggest gender differences in occupational upgrading are apparent in the Mediterranean countries, France and Slovakia. In contrast, there are only minimal gender differences in the Netherlands, Romania and, to a lesser extent, Belgium.

Table 11 Logistic regression model predicting occupational upgrading

\begin{tabular}{|c|c|c|c|c|c|}
\hline & (1) & (2) & (3) & (4) & (5) \\
\hline Intercept & $-1.322^{* * *}$ & $-1.400^{* * *}$ & $-1.197^{* \star *}$ & $0.806^{* * *}$ & $1.094^{\star \star *}$ \\
\hline $\begin{array}{l}\text { Female } \\
\text { (Base: male) }\end{array}$ & $-0.502^{\star \star *}$ & $-0.530^{* * *}$ & $-0.516^{\star * *}$ & $-0.488^{\star * *}$ & $-1.027^{\star * *}$ \\
\hline $\begin{array}{l}\text { Time since leaving } \\
\text { education (months) } \\
\text { Educational level: }\end{array}$ & $0.003^{* * *}$ & $0.003^{* * *}$ & $0.004^{* * *}$ & $0.004^{* \star *}$ & $0.004^{* * *}$ \\
\hline Lower secondary & & -0.023 & $-0.264^{\star *}$ & $-0.691^{* \star *}$ & $-0.692^{* * *}$ \\
\hline $\begin{array}{l}\text { Tertiary } \\
\text { (Base: upper sec.) } \\
\text { Gender }{ }^{\star} \text { Educational } \\
\text { level: }\end{array}$ & & $0.188^{* * *}$ & $0.231^{* * *}$ & $1.090^{\star * *}$ & $1.339^{* * *}$ \\
\hline Female*Lower sec. & & & & & -0.099 \\
\hline \multicolumn{6}{|l|}{ Educational field: } \\
\hline Education & & & $-1.037^{\star \star \star}$ & $-0.641^{* * *}$ & $-1.155^{\star *}$ \\
\hline Arts & & & -0.091 & 0.065 & -0.435 \\
\hline Social Science & & & -0.158 & 0.067 & -0.153 \\
\hline Science & & & -0.056 & $0.397^{* *}$ & 0.312 \\
\hline Engineering & & & $-0.339 * * *$ & $-0.489^{\star \star *}$ & $-0.584^{\star \star *}$ \\
\hline Agriculture & & & $-0.317^{*}$ & $-0.624^{* * *}$ & $-0.753^{* * *}$ \\
\hline Health & & & $-0.651^{* * *}$ & $-0.768^{* * *}$ & -0.614 \\
\hline $\begin{array}{l}\text { Services } \\
\text { (Base. General) }\end{array}$ & & & $-0.341^{* * *}$ & $-0.600^{* \star *}$ & $-0.773^{\star * *}$ \\
\hline \multicolumn{6}{|l|}{$\begin{array}{l}\text { (Base: General) } \\
\text { Gender*Educational } \\
\text { field: }\end{array}$} \\
\hline Female*Education & & & & & 0.747 \\
\hline Female*Arts & & & & & $0.830^{* * *}$ \\
\hline Female*Social science & & & & & $0.355^{\star}$ \\
\hline Female*Science & & & & & 0.213 \\
\hline Female*Engineering & & & & & 0.114 \\
\hline Female*Agriculture & & & & & 0.188 \\
\hline Female*Health & & & & & -0.081 \\
\hline Female*Services & & & & & 0.312 \\
\hline \multicolumn{6}{|l|}{ Labour market history: } \\
\hline Status of first job & & & & $-0.064^{\star \star *}$ & $-0.074^{* * *}$ \\
\hline \multicolumn{6}{|l|}{$\begin{array}{l}\text { Female*Status of first } \\
\text { iob }\end{array}$} \\
\hline $\begin{array}{l}\text { Upgraded educational } \\
\text { level }\end{array}$ & & & & $1.102^{\star \star *}$ & $0.017^{\star * *}$ \\
\hline (Base: did not upgrade) & & & & & $1.355^{\star \star *}$ \\
\hline Female*Upgraded & & & & & \\
\hline educational level & & & & & -0.423 \\
\hline-2 log likelihood & 16286.646 & 16256.461 & 15857.114 & 14746.93 & 14700.034 \\
\hline
\end{tabular}

Note: ${ }^{* * \star} \mathrm{p}<.001,{ }^{* \star} \mathrm{p}<.01$; country and country ${ }^{*}$ gender interactions are controlled for (see Appendix Table A6). 


\section{Summary and conclusions}

Table 12 Summary of country variation in gender differences in early labour market outcomes (controlling for educational level)

\begin{tabular}{|c|c|c|c|c|c|c|c|}
\hline & $\begin{array}{c}\text { Educational } \\
\text { segregation } \\
\text { (outlier) }\end{array}$ & $\begin{array}{c}\text { Occupational } \\
\text { segregation } \\
\text { (outlier) }\end{array}$ & $\begin{array}{c}\text { Labour } \\
\text { market } \\
\text { integration }\end{array}$ & $\begin{array}{l}\text { Labour force } \\
\text { participation }\end{array}$ & $\begin{array}{l}\text { Unemploy- } \\
\text { ment }\end{array}$ & $\begin{array}{l}\text { Occup. } \\
\text { status }\end{array}$ & $\begin{array}{c}\text { Occup. } \\
\text { upgrading }\end{array}$ \\
\hline Austria & + & + & - & - & + & + & n.a. \\
\hline Netherlands & & & 0 & $(-)$ & + & $(-)$ & $(-)$ \\
\hline Sweden & & & $(+)$ & $(-)$ & - & - & - \\
\hline Finland & & & $(-)$ & - & $(-)$ & - & - \\
\hline France & + & & - & - & + & - & - \\
\hline Belgium & & & - & - & + & $(-)$ & - \\
\hline Greece & - & - & - & - & + & + & - \\
\hline Spain & & & - & - & + & + & - \\
\hline Hungary & & & - & - & - & + & - \\
\hline Slovenia & + & & 0 & $(+)$ & 0 & + & - \\
\hline Romania & - & - & 0 & - & - & + & $(-)$ \\
\hline Slovakia & & + & $(+)$ & - & - & + & - \\
\hline
\end{tabular}

+ higher among women; (+) slightly higher among women; 0 no gender difference.

This paper has considered gender differentiation in early labour market outcomes across a range of European countries. As Table 12 illustrates, there are certain commonalities in gender differences across European countries. Women tend to have lower labour force participation rates than their male counterparts and, where they have remained in the labour market, they are less likely to have experienced occupational upgrading. However, there is also cross-national variation in the nature of gender differentiation; this variation is particularly evident in relation to unemployment rates with higher rates among women than men in many central European and Mediterranean countries and lower rates among women than men in many Eastern European and Scandinavian countries.

In spite of the fact that the educational attainment of women has now surpassed that of men in many countries, differences persist in the type of educational courses taken by young women and men. Countries differ in the extent of educational segregation by gender but certain regularities are evident, with health/welfare, education and arts courses dominated by women and engineering courses dominated by men. It had been hypothesised that, at the country level, educational segregation would be positively associated with occupational segregation by gender. It is, indeed, apparent that countries with higher rates of gender segregation within the educational system tend to have higher rates of gender segregation within the labour market. Thus, occupational segregation reflects, at least in part, the way in which the different kinds of courses taken by young women and men channel them into gender-typed occupations. However, it is also apparent that marked gender differences persist among those who have taken similar courses across all countries, both those 
characterised by differentiated, gender-tracked systems and those characterised by more general systems. Thus, labour market segregation also reflects 'post-sorting', whereby women and men with the same kinds of qualifications enter quite different occupational arenas.

As Table 12 illustrates, there is no necessary relationship among the labour market outcomes considered. For instance, women's unemployment is higher than men's in both Austria, a more segregated youth labour market, and Greece, a less segregated youth labour market. Thus, there is no evidence that greater segregation within the youth labour market either hinders or facilitates the integration of young women into stable employment.

To date, much research on gender differentiation and segregation within the labour market has focused on adult workers. This paper indicates the need to investigate the way in which gender differentiation emerges early in the labour market career and the impact of early employment experiences on subsequent career trajectories.

\section{References}

Borghans, L. and Groot, L., 1999: Educational presorting and occupational segregation, Labour Economics 6: 375-395.

Connell, R.W., 1987: Gender and Power, Cambridge: Polity Press.

Iannelli, C., 2001: Report on Data Quality and Cross-country comparability, report to Eurostat.

Kalter, F., 2000: Measuring Segregation and Controlling for Independent Variables, MZES Working Paper no. 19.

Müller, W. and Wolbers, M., 1999: Educational attainment of young people in the European Union: cross-country variation of trends over time, in Müller, W. et al., A Comparative Analysis of Transitions from Education to Work in Europe - Based on the European Community Labour Force Survey, Report to the European Commission.

Rubery, J. and Fagan, C., 1995: Gender segregation in societal context, Work, Employment and Society 9(2): 213-240.

Siltanen, J., Jarman, J. and Blackburn, R.M., 1995: Gender Inequality in the Labour Market: Occupational Concentration and Segregation, Geneva: International Labour Office.

Smyth. E., 2001: Gender differentiation in education and early labour market transitions: a comparative analysis, in Smyth, E. et al., A Comparative Analysis of Transitions from Education to Work in Europe (CATEWE): Annex to the Final Report, Report to the European Commission.

Wolbers, M., 2002: Job mismatches and their labour market effects among young people in Europe, MZES Working Paper no. 47. 


\section{Appendix Tables}

Table A1 Country effects on obtaining a first significant job

\begin{tabular}{|c|c|c|c|c|c|c|}
\hline & $\begin{array}{l}\text { Base } \\
\text { model }\end{array}$ & $\begin{array}{c}\text { Educational } \\
\text { level }\end{array}$ & $\begin{array}{l}\text { Educational } \\
\text { field }\end{array}$ & $\begin{array}{l}\text { Family } \\
\text { status }\end{array}$ & $\begin{array}{l}\text { Education* } \\
\text { gender }\end{array}$ & $\begin{array}{l}\text { Family* } \\
\text { gender }\end{array}$ \\
\hline \multicolumn{7}{|l|}{ Country: } \\
\hline Austria & $0.201^{* * *}$ & 0.087 & 0.011 & $0.182^{\star \star}$ & $0.211^{\star * *}$ & $0.201^{* *}$ \\
\hline Netherlands & $0.769^{* * *}$ & $0.637^{* * *}$ & $0.586^{\star * *}$ & $0.684^{\star * *}$ & $0.733^{\star * *}$ & $0.765^{\star * *}$ \\
\hline Sweden & $1.134^{* * *}$ & $0.828^{* * *}$ & $0.770^{* * *}$ & $0.841^{* * *}$ & $0.939^{* * *}$ & $1.013^{\star * *}$ \\
\hline Finland & -0.014 & $-0.240^{* \star *}$ & $-0.253^{\star * *}$ & -0.134 & -0.102 & -0.027 \\
\hline France & $0.611^{\star * \star}$ & $0.250^{* \star \star}$ & $0.173^{\star * \star}$ & $0.241^{\star * *}$ & $0.286^{\star \star \star}$ & $0.270^{* * *}$ \\
\hline Belgium & $1.081^{* * *}$ & $0.917^{\star * *}$ & $0.947^{\star \star \star}$ & $1.023^{\star * *}$ & $1.059^{\star * *}$ & $1.060^{* * *}$ \\
\hline Greece & $0.274^{\star * *}$ & 0.110 & $0.187^{\star \star *}$ & $0.137^{\star *}$ & $0.182^{\star * \star}$ & $0.198^{\star \star \star}$ \\
\hline Hungary & $0.618^{* * *}$ & $0.469^{* * *}$ & $0.379^{\star * *}$ & $0.485^{\star \star *}$ & $0.486^{* * *}$ & $0.452^{* \star *}$ \\
\hline Slovenia & $0.628^{\star \star \star}$ & $0.425^{\star * \star}$ & $0.268^{\star *}$ & $0.323^{\star * \star}$ & $0.341^{* * *}$ & $0.343^{\star \star *}$ \\
\hline Romania & $-1.165^{\star \star *}$ & $-1.238^{\star * *}$ & $-1.286^{\star * *}$ & $-1.219^{\star \star *}$ & $-1.199^{\star * *}$ & $-1.255^{\star * *}$ \\
\hline Slovakia & $-0.420^{\star \star *}$ & $-0.701^{* * *}$ & $-0.805^{\star * *}$ & -0.389 & -0.300 & -0.299 \\
\hline \multicolumn{7}{|c|}{$\begin{array}{l}\text { Country* gender } \\
\text { interactions: }\end{array}$} \\
\hline $\mathrm{AT}^{*}$ female & $0.252^{* * *}$ & $0.522^{\star \star *}$ & $0.531^{* * *}$ & $0.529^{* * *}$ & $0.494^{* * *}$ & $0.540^{* * *}$ \\
\hline NL*female & $0.481^{* * *}$ & $0.739^{* * *}$ & $0.732^{* * *}$ & $0.650^{* * *}$ & $0.594^{* * *}$ & $0.546^{\star * *}$ \\
\hline SE*female & $0.471^{* * *}$ & $0.763^{* * *}$ & $0.775^{\star * *}$ & $0.762^{* * *}$ & $0.630^{* * *}$ & $0.508^{* * *}$ \\
\hline Fl*female & $0.502^{* \star *}$ & $0.666^{\star * *}$ & $0.661^{* * *}$ & $0.641^{* * *}$ & $0.602^{* * *}$ & $0.475^{\star \star \star}$ \\
\hline $\mathrm{FR}^{\star}$ female & $0.182^{* * *}$ & $0.370^{* * *}$ & $0.390^{* * *}$ & $0.416^{\star * *}$ & $0.341^{* * *}$ & $0.405^{\star * *}$ \\
\hline$B E^{*}$ female & 0.003 & 0.073 & 0.024 & 0.043 & -0.003 & 0.029 \\
\hline $\mathrm{GR}^{*}$ female & $-0.247^{* * *}$ & -0.112 & -0.085 & -0.072 & -0.139 & -0.157 \\
\hline HU*female & $0.288^{\star \star *}$ & $0.522^{* * *}$ & $0.552^{* * *}$ & $0.587^{\star \star *}$ & $0.614^{* * *}$ & $0.706^{\star * *}$ \\
\hline SI*female & $0.555^{\star * *}$ & $0.676^{\star * *}$ & $0.749^{* * *}$ & $0.802^{* * *}$ & $0.786^{* * *}$ & $0.829^{* * *}$ \\
\hline RO*female & $0.427^{* \star *}$ & $0.716^{\star * *}$ & $0.720^{* * *}$ & $0.759^{\star * \star}$ & $0.772^{\star * *}$ & $0.890^{* \star *}$ \\
\hline SK*female & $0.526^{\star * *}$ & $0.814^{* * *}$ & $0.830^{* * *}$ & -0.160 & -0.282 & -0.295 \\
\hline
\end{tabular}

Note: corresponds to Table 4 above.

Table A2 Country effects on labour force participation

\begin{tabular}{|c|c|c|c|c|c|}
\hline & Base model & $\begin{array}{c}\text { Educational } \\
\text { level }\end{array}$ & $\begin{array}{l}\text { Educational } \\
\text { field }\end{array}$ & $\begin{array}{l}\text { Family } \\
\text { status }\end{array}$ & $\begin{array}{l}\text { Family* } \\
\text { gender }\end{array}$ \\
\hline \multicolumn{6}{|l|}{ Country: } \\
\hline Austria & $-0.713^{\star \star *}$ & $-0.930^{* * *}$ & $-1.020^{* * *}$ & $-0.511^{* * *}$ & $-0.314^{* *}$ \\
\hline Netherlands & -0.175 & -0.344 & -0.386 & -0.005 & 0.298 \\
\hline Sweden & $-1.088^{* \star *}$ & $-1.480^{* * *}$ & $-1.514^{* * *}$ & $-1.365^{\star * *}$ & $-0.884^{* * *}$ \\
\hline Finland & $-0.861^{* * *}$ & $-1.140^{\star * *}$ & $-1.141^{* * *}$ & $-0.801^{* * *}$ & -0.200 \\
\hline France & -0.050 & $-0.453^{* * *}$ & $-0.532^{* \star *}$ & $-0.368^{\star * *}$ & $-0.411^{* * *}$ \\
\hline Belgium & 0.219 & -0.043 & 0.059 & 0.270 & 0.413 \\
\hline Greece & $-0.372^{\star \star \star}$ & $-0.599^{\star \star \star}$ & $-0.502^{\star \star \star}$ & $-0.713^{\star \star *}$ & $-0.641^{* \star *}$ \\
\hline Hungary & $-1.140^{\star * *}$ & $-1.389^{* * *}$ & $-1.445^{\star * *}$ & $-1.249^{\star * *}$ & $-1.371^{\text {** }}$ \\
\hline Slovenia & $-0.946^{\star \star *}$ & $-1.260^{\star * *}$ & $-1.392^{\star \star *}$ & $-1.308^{\star * *}$ & $-1.347^{* \star *}$ \\
\hline Romania & $-0.906^{\star * *}$ & $-0.976^{\star * *}$ & $-0.989^{* * *}$ & $-0.811^{\star * *}$ & $-1.023^{* * *}$ \\
\hline Slovakia & 0.079 & -0.280 & $-0.367^{* *}$ & $-4.116^{\star * *}$ & $-3.458^{* * *}$ \\
\hline \multicolumn{6}{|c|}{ Country $^{*}$ gender interactions: } \\
\hline$A T *$ female & -0.001 & 0.224 & 0.236 & 0.148 & -0.109 \\
\hline $\mathrm{NL}^{*}$ female & 0.412 & $0.633^{* \star}$ & $0.643^{\star \star}$ & 0.437 & 0.018 \\
\hline SE*female & $0.501^{* * *}$ & $0.684^{* * *}$ & $0.682^{* * *}$ & $0.630^{\star * *}$ & -0.133 \\
\hline Fl*female & -0.007 & 0.079 & 0.091 & -0.011 & $-0.938^{* * *}$ \\
\hline $\mathrm{FR}^{\star}$ female & $-0.341^{* * *}$ & -0.224 & $-0.249^{* *}$ & -0.197 & -0.077 \\
\hline $\mathrm{BE}^{\star}$ female & -0.396 & -0.362 & -0.463 & -0.453 & $-0.597^{* *}$ \\
\hline GR*female & $-0.305^{\star \star}$ & -0.216 & -0.199 & -0.145 & -0.247 \\
\hline HU*female & $-0.433^{\star \star *}$ & $-0.277^{\star *}$ & $-0.291^{* * *}$ & $-0.242^{* *}$ & -0.066 \\
\hline SI*female & $0.940^{\star * *}$ & $1.050^{\star * *}$ & $1.034^{\star * *}$ & $1.249^{\star * *}$ & $1.350^{\text {** }}$ \\
\hline RO*female & -0.155 & 0.052 & 0.032 & 0.093 & $0.433^{* * *}$ \\
\hline SK*female & $-1.184^{\star \star *}$ & $-0.968^{\star \star *}$ & $-0.973^{\star * *}$ & 0.947 & -0.220 \\
\hline
\end{tabular}

Note: corresponds to Table 5 above. 
Table A3 Country effects on current unemployment

\begin{tabular}{|c|c|c|c|c|}
\hline & Base model & $\begin{array}{l}\text { Educational } \\
\text { level }\end{array}$ & $\begin{array}{l}\text { Educational } \\
\text { field }\end{array}$ & $\begin{array}{l}\text { Education* } \\
\text { gender }\end{array}$ \\
\hline \multicolumn{5}{|l|}{ Country: } \\
\hline Austria & $-1.769^{\star \star \star}$ & $-1.795^{\star * *}$ & $-1.740^{\star * *}$ & $-1.723^{* * *}$ \\
\hline Netherlands & $-2.276^{\star \star \star}$ & $-2.259^{\star \star \star}$ & $-2.251^{* * *}$ & $-2.265^{\star \star \star}$ \\
\hline Sweden & $-0.958^{\star * \star}$ & $-0.814^{\star * *}$ & $-0.801^{* * *}$ & $-0.839^{* * *}$ \\
\hline Finland & -0.088 & 0.011 & 0.036 & 0.056 \\
\hline France & $-0.192^{* * *}$ & 0.037 & 0.073 & 0.073 \\
\hline Belgium & $-0.591^{* * *}$ & $-0.485^{\star * *}$ & $-0.472^{\star * \star}$ & $-0.478^{\star * \star}$ \\
\hline Greece & $0.322^{* * *}$ & $0.386^{* * *}$ & $0.371^{* * *}$ & $0.366^{\star * *}$ \\
\hline Hungary & $-0.250^{* * \star}$ & $-0.201^{* *}$ & $-0.178^{\star *}$ & -0.137 \\
\hline Slovenia & $-0.473^{* * \star}$ & $-0.411^{* * *}$ & $-0.361^{* *}$ & $-0.333^{\star *}$ \\
\hline Romania & $1.016^{\star * \star}$ & 0.062 & 0.061 & 0.060 \\
\hline Slovakia & $-0.473^{* * *}$ & $1.095^{\star \star \star}$ & $1.123^{* \star *}$ & $1.188^{\star * *}$ \\
\hline \multicolumn{5}{|c|}{ Country ${ }^{*}$ gender interactions: } \\
\hline $\mathrm{AT}^{*}$ female & -0.251 & -0.426 & -0.454 & -0.483 \\
\hline NL*female & 0.256 & 0.067 & 0.076 & 0.087 \\
\hline SE*female & $-0.777^{\star * \star}$ & $-0.976^{\star * *}$ & $-0.975^{\star * *}$ & $-0.940^{* * *}$ \\
\hline $\mathrm{FI}^{\star}$ female & $-0.699^{* * *}$ & $-0.803^{* * *}$ & $-0.815^{\star * *}$ & $-0.867^{\star \star *}$ \\
\hline $\mathrm{FR}^{\star}$ female & $-0.304^{* * *}$ & $-0.429^{* * *}$ & $-0.483^{\star * *}$ & $-0.476^{\star * *}$ \\
\hline $\mathrm{BE}^{\star}$ female & $-0.331^{* * *}$ & -0.360 & -0.352 & -0.357 \\
\hline $\mathrm{GR}^{\star}$ female & -0.003 & -0.092 & -0.106 & -0.114 \\
\hline $\mathrm{HU}^{\star}$ female & $-0.889^{\star \star *}$ & $-1.040^{\star * *}$ & $-1.053^{\star \star *}$ & $-1.159^{\star \star *}$ \\
\hline SI*female & $-0.600^{\star \star *}$ & $-0.655^{\star \star \star}$ & $-0.730^{\star \star *}$ & $-0.807^{\star * *}$ \\
\hline RO*female & $-0.875^{\star \star \star}$ & $-1.062^{* * *}$ & $-1.068^{\star * *}$ & $-1.121^{\text {***}}$ \\
\hline $\mathrm{SK}^{*}$ female & $-0.771^{* * *}$ & $-0.974^{\star * *}$ & $-0.993^{\star * *}$ & $-1.164^{\star * \star}$ \\
\hline
\end{tabular}

Note: corresponds to Table 6 above.

Table A4 Country effects on gender-typing of first significant job

\begin{tabular}{|c|c|c|}
\hline & Male & Female \\
\hline \multicolumn{3}{|l|}{ Country: } \\
\hline Austria & $-1.034^{\star * *}$ & $-1.977^{\star \star *}$ \\
\hline Netherlands & $-1.509^{\star \star *}$ & $-2.522^{\star \star *}$ \\
\hline Sweden & $-1.511^{\star * *}$ & $-2.195^{\star * *}$ \\
\hline Finland & $-0.685^{\star * *}$ & $-1.059^{\star * *}$ \\
\hline France & $-1.125^{\star \star *}$ & $-2.419^{\star * *}$ \\
\hline Belgium & $-0.613^{\star \star \star}$ & $-0.779^{* \star *}$ \\
\hline Greece & -0.087 & $-0.683^{\star * *}$ \\
\hline Spain & $5.850^{\star \star \star}$ & $5.123^{\star \star *}$ \\
\hline Slovenia & $-0.599^{* * *}$ & $-0.882^{* * *}$ \\
\hline Romania & -0.185 & $-1.608^{* * *}$ \\
\hline Slovakia & $0.439^{* * *}$ & -0.219 \\
\hline \multicolumn{3}{|c|}{ Country ${ }^{*}$ gender interactions: } \\
\hline $\mathrm{AT}^{*}$ female & $-1.087^{* \star *}$ & -0.314 \\
\hline $\mathrm{NL}^{*}$ female & $-1.370^{\star \star *}$ & -0.121 \\
\hline SE*female & $-0.820^{* * *}$ & -0.024 \\
\hline $\mathrm{Fl}{ }^{\star}$ female & $-0.846^{\star * *}$ & -0.226 \\
\hline FRfemale & $-0.677^{* \star *}$ & $0.338^{* *}$ \\
\hline$B E^{\star}$ female & -0.353 & -0.008 \\
\hline $\mathrm{GR}^{\star}$ female & $-0.933^{\star \star *}$ & $-0.528^{* * *}$ \\
\hline ES*female & -0.613 & -0.147 \\
\hline SI*female & -0.235 & -0.418 \\
\hline RO*female & $-0.552^{\star \star * *}$ & -0.040 \\
\hline SK*female & -0.440 & $-0.478^{* *}$ \\
\hline
\end{tabular}

Note: corresponds to Table 9 above. 
Table A5 Country effects on occupational status

\begin{tabular}{|c|c|c|c|c|}
\hline & Base model & $\begin{array}{l}\text { Educational } \\
\text { level }\end{array}$ & $\begin{array}{l}\text { Educational } \\
\text { field }\end{array}$ & $\begin{array}{l}\text { Education* } \\
\text { gender }\end{array}$ \\
\hline \multicolumn{5}{|l|}{ Country: } \\
\hline Austria & $2.569^{* * *}$ & $6.085^{* * *}$ & $6.448^{* * *}$ & $7.172^{\star * *}$ \\
\hline Netherlands & $8.811^{\star \star \star}$ & $7.810^{\star * *}$ & $7.715^{\star \star \star}$ & $7.793^{* * *}$ \\
\hline Sweden & $5.274^{\star \star *}$ & $4.831^{* * *}$ & $4.327^{\star \star \star}$ & $4.588^{* * *}$ \\
\hline Finland & $4.000^{* \star *}$ & $4.177^{\star \star \star}$ & $5.057^{\star \star \star}$ & $5.217^{* \star \star}$ \\
\hline France & $3.601^{* * *}$ & $0.645^{\star *}$ & $0.787^{* * *}$ & $1.050^{* * *}$ \\
\hline Belgium & $4.595^{\star * *}$ & $3.655^{\star * *}$ & $3.386^{\star * *}$ & $3.429^{* * *}$ \\
\hline Greece & $2.516^{\star * *}$ & $3.897^{\star \star \star}$ & $3.465^{\star \star \star}$ & $3.615^{\star \star \star}$ \\
\hline Hungary & 0.039 & $3.274^{\star * *}$ & $4.322^{\star \star \star}$ & $4.938^{* * *}$ \\
\hline Slovenia & $2.544^{* * *}$ & $4.703^{\star \star *}$ & $5.991^{\star * *}$ & $6.572^{* \star *}$ \\
\hline Romania & $-1.101^{* * *}$ & $1.753^{\star \star \star}$ & $2.110^{* \star *}$ & $2.605^{\star \star *}$ \\
\hline Slovakia & -0.950 & $2.064^{\star * *}$ & $3.670^{* * *}$ & $4.461^{\star \star \star}$ \\
\hline \multicolumn{5}{|c|}{ Country ${ }^{*}$ gender interactions: } \\
\hline $\mathrm{AT}^{*}$ female & $-2.774^{* * *}$ & 0.399 & -0.248 & $-1.925^{\star * *}$ \\
\hline NL*female & $-7.086^{\star * \star}$ & $-3.045^{\star \star *}$ & $-2.811^{\star * *}$ & $-3 \cdot 317^{* \star *}$ \\
\hline SE*female & $-7.346^{\star \star \star}$ & $-4.775^{\star \star \star}$ & $-4.692^{* * *}$ & $-5.409^{* * *}$ \\
\hline FI*female & $-4.973^{\star * *}$ & $-4.453^{\star * *}$ & $-4.634^{* * *}$ & $-4.900^{\star * *}$ \\
\hline $\mathrm{FR}^{\star}$ female & $-5.025^{\star * *}$ & $-3.123^{* * *}$ & $-3.711^{* * *}$ & $-4.275^{\star * *}$ \\
\hline $\mathrm{BE}^{\star}$ female & $-2.979^{\star * *}$ & $-2.617^{\star * *}$ & $-2.037^{\star * *}$ & $-2.132^{\star * *}$ \\
\hline $\mathrm{GR}^{\star}$ female & -0.357 & $1.278^{* *}$ & $1.267^{\star *}$ & 0.581 \\
\hline $\mathrm{HU}^{\star}$ female & -1.049 & $1.492^{\star *}$ & 0.744 & -0.833 \\
\hline SI*female & -0.089 & 0.714 & -0.538 & $-1.950^{\star \star}$ \\
\hline RO*female & -0.148 & $3.203^{\star * *}$ & $2.715^{\star \star \star}$ & 1.152 \\
\hline $\mathrm{SK}^{*}$ female & -0.925 & $2.625^{\star * *}$ & $1.590^{* *}$ & -0.467 \\
\hline
\end{tabular}

Note: corresponds to Table 10 above.

Table A6 Country effects on occupational upgrading

\begin{tabular}{|c|c|c|c|c|c|}
\hline & $\begin{array}{l}\text { Base } \\
\text { model }\end{array}$ & $\begin{array}{l}\text { Educational } \\
\text { level }\end{array}$ & $\begin{array}{l}\text { Educational } \\
\text { field }\end{array}$ & LM history & $\begin{array}{l}\text { LM history* } \\
\text { gender }\end{array}$ \\
\hline \multicolumn{6}{|l|}{ Country: } \\
\hline Netherlands & 0.289 & 0.308 & 0.398 & $0.934^{* *}$ & $1.102^{\star *}$ \\
\hline Sweden & 0.269 & 0.242 & 0.291 & 0.434 & $0.513^{* *}$ \\
\hline Finland & 0.199 & 0.217 & 0.244 & $0.551^{* * *}$ & $0.623^{* * *}$ \\
\hline France & $0.869^{\star \star *}$ & $0.852^{* \star *}$ & $0.884^{\star * *}$ & $1.007^{\star \star *}$ & $1.118^{\star * *}$ \\
\hline Belgium & $0.343^{\star *}$ & $0.329^{\star \star}$ & $0.329^{\star *}$ & $0.562^{\star \star \star}$ & $0.623^{* * *}$ \\
\hline Greece & -0.369 & -0.350 & -0.356 & -0.046 & 0.023 \\
\hline Hungary & -0.008 & 0.033 & 0.110 & $0.362^{\star \star \star *}$ & $0.460^{* * *}$ \\
\hline Slovenia & 0.210 & 0.239 & 0.331 & $0.740^{\star * *}$ & $0.884^{* * *}$ \\
\hline Romania & $-0.809^{\star * *}$ & $-0.778^{\star \star \star}$ & $-0.756^{\star \star *}$ & $-0.589^{\star \star}$ & $-0.510^{* *}$ \\
\hline Slovakia & 0.005 & 0.041 & 0.138 & $0.358^{* *}$ & $0.464^{* * *}$ \\
\hline \multicolumn{6}{|c|}{$\begin{array}{l}\text { Country* gender } \\
\text { interactions: }\end{array}$} \\
\hline NL*female & 0.477 & 0.489 & 0.431 & 0.247 & -0.010 \\
\hline SE*female & 0.070 & 0.137 & 0.165 & 0.045 & -0.110 \\
\hline Fl*female & 0.111 & 0.106 & 0.130 & -0.075 & -0.188 \\
\hline FR*female & -0.086 & -0.069 & -0.137 & -0.285 & $-0.479^{* * *}$ \\
\hline BE*female & 0.235 & 0.244 & 0.254 & 0.269 & 0.142 \\
\hline $\mathrm{GR}^{\star}$ female & -0.665 & -0.654 & -0.680 & -0.588 & -0.769 \\
\hline HUfemale & 0.124 & 0.141 & 0.085 & 0.216 & 0.015 \\
\hline SI*female & 0.186 & 0.190 & 0.124 & 0.145 & -0.130 \\
\hline RO*female & 0.416 & 0.444 & 0.426 & 0.584 & 0.384 \\
\hline SK*female & -0.093 & -0.061 & -0.122 & 0.003 & -0.216 \\
\hline
\end{tabular}

Note: corresponds to Table 11 above. 